\title{
Effects of jugular infused methionine, lysine, and histidine as a group or leucine and isoleucine as a group on production and metabolism in lactating dairy cows
}

\author{
P. S. Yoder, ${ }^{1,2} \odot$ X. Huang, ${ }^{1} \odot$ I. A. Teixeira, ${ }^{3} \oplus$ J. P. Cant,${ }^{4}{ }^{\oplus}$ and M. D. Hanigan ${ }^{1 *} \odot$ \\ ${ }^{1}$ Department of Dairy Science, Virginia Tech, Blacksburg 24061 \\ ${ }^{2}$ Perdue AgriBusiness LLC, Salisbury, MD 21804 \\ ${ }^{3}$ UNESP, Jaboticabal, 14884-900 Brazil \\ ${ }^{4}$ Department of Animal Biosciences, University of Guelph, Ontario, N1G 2W1 Canada
}

\section{ABSTRACT}

Essential AA (EAA), particularly leucine, isoleucine, methionine, and histidine, possess signaling properties for promoting cellular anabolic metabolism, whereas methionine, lysine, and histidine are considered also to be substrate limiting AA. The objective of this study was to evaluate production responses to supplementation of $2 \mathrm{AA}$ groups in a $2 \times 2$ factorial design. Eight cows (99 \pm 18 days in milk) were assigned to 4 jugular infusion treatments consisting of saline $(\mathrm{CON})$, methionine plus lysine plus histidine $(\mathrm{MKH})$, isoleucine plus leucine (IL), or MKH plus IL, in a replicated 4 $\times 4$ Latin square design. Periods were $18 \mathrm{~d}$ in length, comprising $8 \mathrm{~d}$ of rest followed by $10 \mathrm{~d}$ of jugular infusion. Daily infusion amounts were $21 \mathrm{~g}$ of methionine, $38 \mathrm{~g}$ of lysine, $20 \mathrm{~g}$ of histidine, $50 \mathrm{~g}$ of leucine, and $22 \mathrm{~g}$ of isoleucine. Cows were ad libitum fed a common diet consisting of $15.2 \%$ crude protein and 1.61 $\mathrm{Mcal} / \mathrm{kg} \mathrm{NE} \mathrm{L}_{\mathrm{L}}$ on a dry matter basis that was predicted to meet rumen degradable protein requirements but was $15 \%$ deficient in metabolizable protein. Milk and energy-corrected milk yields increased by $2.3 \mathrm{~kg} / \mathrm{d}$ and $1.9 \mathrm{~kg} / \mathrm{d}$, respectively, with infused IL, and no change was observed for MKH. Milk protein concentration increased by 0.13 percentage units for $\mathrm{MKH}$, whereas milk protein yield increased for both MKH and IL by $84 \mathrm{~g} / \mathrm{d}$ and $64 \mathrm{~g} / \mathrm{d}$, respectively. The milk protein yield increase for $\mathrm{MKH}^{+} \mathrm{IL}$ was $145 \mathrm{~g} / \mathrm{d}$ versus CON. Gross feed efficiency tended to increase with IL infusion, and $\mathrm{N}$ efficiency tended to increase with $\mathrm{MKH}$ infusion. Aggregate arterial EAA concentrations less Met, Lys, and His declined by $7.2 \%$ in response to MKH infusion. Arterial EAA less Ile and Leu also declined by $6.2 \%$ in response to IL infusion. Net total AA (TAA) and EAA

Received June 8, 2019.

Accepted November 4, 2019.

*Corresponding author: mhanigan@vt.edu uptake by the udder tended to increase in response to MKH infusion, whereas mammary blood flow increased in response to IL infusion, but TAA and EAA net uptakes were unaffected. Apparent udder affinity increased for TAA and EAA less Met, Lys, and His in response to MKH infusion, whereas affinity for EAA less Ile and Leu increased for IL infusion. Venous Met and Leu concentrations increased by $192 \%$ and $35 \%$ from the MKH and IL infusions, respectively, compared with CON, which indicates that intracellular concentration of these EAA changed substantially. Increases in milk protein yield were observed from 2 groups of amino acids independently and additively, which contradicts the single limiting amino acid theory that a single EAA will limit milk protein yield.

Key words: milk protein, methionine, lysine, histidine, leucine, isoleucine

\section{INTRODUCTION}

Improving our ability to manipulate milk protein yield to increase profitability and $\mathrm{N}$ efficiency, the latter being quite low at 25\% (Hristov et al., 2004), is critical for human food supply security and industry sustainability. Milk protein yield is determined by AA availability and enzyme catalytic potential, with the former considered to be the major regulator of milk protein synthesis.

Mitchell and Block (1946) formulated a conceptual framework using the assumption that the most limiting AA regulates synthesis, and addition of other AA will have no effect. The most limiting EAA for milk protein production are considered to be Met, Lys, and possibly His. Milk protein responses to Met are well documented and fairly consistent, and responses to Lys and His are somewhat more variable but have often been observed (Schwab et al., 1976; Lee et al., 2012; Giallongo et al., 2017). However, the conceptual framework of Mitchell and Block (1946) can yield variable and unpredictable 
responses (Hanigan et al., 2000). For example, in diets less than $15 \% \mathrm{CP}$, supplementation of Met and Lys resulted in no overall benefit in fat-corrected milk yield and only a small benefit in milk protein yield across 16 experiments (Sinclair et al., 2014). Greater understanding of the mechanisms mediating the effects of Met, Lys, and His on milk protein yield, and interactions with other factors, is needed to better predict responses to supplementation of these EAA.

Net AA uptake by the udder as a proportion of arterial daily AA influx is quite low, having been shown to be $22 \%$ (Hanigan et al., 2004). This leaves a significant proportion of arterial AA available for splanchnic tissue metabolism. Given such a low udder capture of AA, a logical strategy for improving $\mathrm{N}$ efficiency is to increase intracellular demand via increased protein synthesis rates, which would increase the uptake of AA from arterial supplies and decrease AA available for splanchnic metabolism. Changes in phosphorylation of translation factors related to protein synthesis rate and milk protein yield have been observed in vitro and in a few in vivo trials (Rius et al., 2010; Toerien et al., 2010; Arriola Apelo et al., 2014c). Mechanistically, Leu appears to be the most potent of the EAA for activating protein translation. This occurs through Leu binding to Sestrin2 in the cytoplasm, which disrupts the GATOR2-Sestrin2 bond (Saxton et al., 2016). Methionine and Arg mechanistically have also been linked to mTOR regulation (Sabatini, 2017).

Evidence that supplementing Leu or the branchedchain AA (BCAA) increases milk protein yield or phosphorylation of translation factors is not well documented, particularly in longer-term studies ( $>5 \mathrm{~d}$; Arriola Apelo et al., 2014a; Doelman et al., 2015b; Nichols et al., 2017). Infusion of BCAA has not increased milk protein yield in several studies (Korhonen et al., 2002; Appuhamy et al., 2011; Curtis et al., 2018). Several reasons may exist for the lack of a response to BCAA: the $\mathrm{BCAA}$ were not limiting, inappropriate $\mathrm{BCAA}$ infusion amounts, other EAA were more limiting, BCAA caused transport competition for EAA uptake, or BCAA stimulated increased nonmammary tissue use of EAA. Experiments using removal of BCAA or Leu from treatment EAA infusate as a model have shown negative effects on milk protein yield (Rulquin and Pisulewski, 2006; Doelman et al., 2015b; Tian et al., 2017), whereas others have shown no response (Weekes et al., 2006).

We propose several treatment variants from previous studies to better assess responses of lactating cows. First, infusion of only Leu and Ile instead of all BCAA, since only Leu and Ile are known to possess strong mTOR signaling properties. Second, infusion amounts that are similar to replacing the observed Leu and Ile supplies in typical industry diets and that are large enough to elicit a change in blood plasma concentrations. Last, utilizing high-producing dairy cows (approximately $50 \mathrm{~kg} / \mathrm{d}$ milk production) might also yield different results than the previously mentioned studies. Regarding AA transport, Val competes for cellular uptake with Leu and Ile by using System L transporters (Shennan and Boyd, 2014). Although speculative, addition of Val to BCAA infusates may counteract the benefits of Leu and Ile. This hypothesis regarding Val is also supported by a recent meta-analysis that found a negative milk protein response to increasing Val dietary supplies (Hanigan et al., 2018).

We hypothesized that supplementation of Met, Lys, and His as a group and Ile and Leu as a group would independently increase milk protein yield and that these effects would be additive. The objectives of this study were to determine milk yield and milk component responses to these 2 groups of EAA in dairy cows $(>50$ $\mathrm{kg}$ milk/d) and to observe changes in metabolism that may mediate changes in milk protein yield.

\section{MATERIALS AND METHODS}

\section{Experimental Design, Animals, and Feeding Management}

All animal procedures were approved by the Virginia Tech Animal Care and Use Committee. Eight Holstein cows in second lactation were blocked by DIM (2 blocks) and randomly assigned to 1 of 4 treatment sequences in a $2 \times 2$ factorial arrangement in 2 orthogonally replicated $4 \times 4$ Latin squares. For 1 of the blocks, cows were biopsied for muscle and mammary tissue on d 18 ( $\mathrm{n}=4$ cows) for assessment of posttranslation modification of proteins by proteomics, whereas the cows in the other block were infused in the jugular with isotopically labeled algae $(\mathrm{n}=4$ cows $)$ to measure bidirectional transport of AA in the mammary gland. The data related to tissue biopsies and isotope tracing of metabolism are not presented herein and will be presented in future publications. Treatments were jugular infusion of saline (CON); methionine, lysine, and histidine (MKH); isoleucine and leucine (IL); and the combination of $\mathrm{MKH}$ and IL $\left(\mathbf{M K H} \mathbf{H}^{+} \mathbf{I L}\right)$. Before the experiment, all cows were fed the experimental diet (Table 1, Table 2) for $28 \mathrm{~d}$ for adaptation. Period length was 18. At the beginning of the experiment (i.e., before the adaptation period), animals averaged 71 DIM (18 d SD). Cows were housed in a 12-unit freestall pen for the adaptation period and the first $8 \mathrm{~d}$ of each period. On d 8 of each period, cows were moved to individual metabolism stalls and housed until d 18 of each period. Cows were fed a TMR ad libitum twice daily in the 
metabolism stalls, with a target minimum refusal of $5 \%$, and milked twice daily at 0100 and $1230 \mathrm{~h}$. Starting at $1200 \mathrm{~h}$ on $\mathrm{d} 15$, cows were fed every $2 \mathrm{~h}$ for 36 $\mathrm{h}$ at $100 \%$ of the observed previous 7 -d DMI average to standardize feed intake for blood flow and isotope infusion measurements. Milk, feed intake, and body weight were recorded daily. The corn silage was from plants containing the brown midrib 3 gene and was sourced from a single silage bag. Corn silage DM was assayed 5 times per period in duplicate by drying for 24 $\mathrm{h}$ at $100^{\circ} \mathrm{C}$. Dietary adjustments were made when DM changed by more than 2 units. Refusals and TMR DM were assayed 3 times per period by drying for $24 \mathrm{~h}$ at $100^{\circ} \mathrm{C}$. Corn silage, alfalfa hay, corn grain, wet brewers grain, grain mix, and TMR were sampled 3 times per period, composited by period, and stored at $-20^{\circ} \mathrm{C}$. Ingredients were assayed for DM using a forced-air oven at $55^{\circ} \mathrm{C}$ for $48 \mathrm{~h}$ and then sent to Cumberland Valley Analytical Services (Waynesboro, PA) for analysis of $\mathrm{CP}, \mathrm{ADF}, \mathrm{NDF}$ on an $\mathrm{OM}$ basis, lignin, in vitro (IV)NDF digestibility $30 \mathrm{~h}, \mathrm{IV}-\mathrm{NDF} 120 \mathrm{~h}$, IV-NDF $240 \mathrm{~h}$, acid detergent insoluble $\mathrm{CP}$, neutral detergent insoluble $\mathrm{CP}$, soluble CP, ammonia, starch, IV-Starch $7 \mathrm{~h}$, ether extract, fatty acids, ash, minerals, and fermentation [Cumberland Valley Analytical NIR2 (near-infrared spectroscopy) package; Supplemental Table S1, https:/ /doi.org/10.3168/jds.2019-17082].

Cows were fed a common diet during the entire study, including the adaptation period, which was formulated to meet requirements for energy, rumen-degradable protein, minerals, and vitamins, but to be deficient in metabolizable protein for a $680-\mathrm{kg}$ Holstein cow producing $47 \mathrm{~kg}$ of milk containing $3.60 \%$ fat and $3.10 \%$ protein (Table 1, Table 2). The amount of jugularinfused amino acids for the MKH $(21 \mathrm{~g} / \mathrm{d}$ of Met, 20 $\mathrm{g} / \mathrm{d}$ of His, and $38 \mathrm{~g} / \mathrm{d}$ of Lys) and IL $(22 \mathrm{~g} / \mathrm{d}$ of Ile and $50 \mathrm{~g} / \mathrm{d}$ of Leu) treatments was estimated based on meta-analytical work in progress, predictions from the NDS Professional ration formulation software (version 6.55; RUM\&N, NDS Professional, Reggio Nell'Emilia, Emilia-Romagna, Italy), the amounts of each AA contained in a typical diet containing heat-treated soybean meal, blood meal, and rumen-protected methionine, and the recommended supply relative to metabolizable energy supply (Supplemental Table S2, https:// doi.org/10.3168/jds.2019-17082; Van Amburgh et al., 2015). The ratio of Lys to Met supplied from the diet plus infusate was targeted at 2.65 to 1 , whereas the ratio of Leu to Ile was targeted to be similar to what is observed in true milk protein (1.67 to 1; Lapierre et al., 2012). Leucine and Ile are metabolized with similar efficiencies from absorbed protein supplies (Myers et al., 2018); hence, the targeted ratio. The amount of Leu
Table 1. Average ingredient composition of the experimental diet $(\%$ of DM)

\begin{tabular}{|c|c|c|}
\hline Item & Mean & $\mathrm{SD}$ \\
\hline Corn silage & 38.1 & 2.4 \\
\hline Alfalfa hay & 9.37 & 1.2 \\
\hline Wet brewers & 9.26 & 0.81 \\
\hline Corn grain & 20.2 & 4.4 \\
\hline Soybean meal & 7.43 & 0.48 \\
\hline Citrus pulp, dry & 6.39 & 0.41 \\
\hline Soybean hulls, ground & 4.04 & 0.26 \\
\hline Palmitic enriched fat supplement ${ }^{1}$ & 1.12 & 0.070 \\
\hline Sodium bicarbonate $^{2}$ & 0.943 & 0.061 \\
\hline Calcium carbonate & 0.600 & 0.039 \\
\hline Potassium carbonate $^{3}$ & 0.495 & 0.032 \\
\hline Molasses & 0.314 & 0.020 \\
\hline Dicalcium phosphate & 0.419 & 0.027 \\
\hline Urea & 0.210 & 0.014 \\
\hline Sodium bentonite $^{4}$ & 0.191 & 0.012 \\
\hline Omnigen $^{5}$ & 0.171 & 0.011 \\
\hline Salt & 0.181 & 0.012 \\
\hline Magnesium oxide & 0.171 & 0.011 \\
\hline Potassium chloride red & 0.162 & 0.010 \\
\hline Magnesium potassium sulfate & 0.0861 & 0.0064 \\
\hline Flow matrix & 0.0480 & 0.0033 \\
\hline Trace minerals and vitamins ${ }^{7}$ & 0.0672 & 0.0041 \\
\hline
\end{tabular}

${ }^{1}$ Palmit 80, Global Agri-Trade Corp., Long Beach, CA.

${ }^{2}$ Church and Dwight Co. Inc., Princeton, NJ.

${ }^{3}$ DCAD PLUS, Church and Dwight Co. Inc.

${ }^{4}$ AB-20, Prince Agri Products Inc., Quincy, IL.

${ }^{5}$ Prince Agri Products Inc.

${ }^{6} \mathrm{PMI}$ Nutritional Additives, Arden Hills, MN.

${ }^{7}$ Contained $221 \mathrm{mg}$ of $\mathrm{Mn}, 140 \mathrm{mg}$ of $\mathrm{Cu}, 2 \mathrm{mg}$ of Fe, $397 \mathrm{mg}$ of $\mathrm{Zn}$, and $15 \mathrm{mg}$ of Co from Availa 4 (Zinpro Corp., Eden Prairie, MN), 16 $\mathrm{mg}$ of I (calcium iodate), $7.3 \mathrm{mg}$ of Se (Sel-Plex 2000, Alltech Inc., Nicholasville, KY), $131 \mathrm{kIU}$ of vitamin A, $30 \mathrm{kIU}$ of vitamin D, and $550 \mathrm{IU}$ of vitamin E.

and Ile infused was limited by the solubility of Leu in $3 \mathrm{~L}$ of saline.

\section{Jugular Infusions and Catheterizations}

Pharmaceutical-grade L-methionine, L-histidine, Llysine- $\mathrm{HCl}$, L-isoleucine, and L-leucine were obtained from ACP Chemicals (Toronto, ON, Canada). Infusates were prepared approximately 1 to $3 \mathrm{~d}$ before jugular infusion by dissolving $21 \mathrm{~g}$ of methionine, 20 $\mathrm{g}$ of histidine, and $47.5 \mathrm{~g}$ of lysine- $\mathrm{HCl}$ in $3 \mathrm{~L}$ of $0.9 \%$ saline for the MKH treatment; $22 \mathrm{~g}$ of isoleucine and 50 $\mathrm{g}$ of leucine in $3 \mathrm{~L}$ of $0.9 \%$ saline for the IL treatment; and $21 \mathrm{~g}$ of methionine, $20 \mathrm{~g}$ of histidine, $47.5 \mathrm{~g}$ of lysine- $\mathrm{HCl}, 22 \mathrm{~g}$ of isoleucine, and $50 \mathrm{~g}$ of leucine in 3 $\mathrm{L}$ of $0.9 \%$ saline for the $\mathrm{MKH}^{+} \mathrm{IL}$ treatment. The $0.9 \%$ saline was pharmaceutical-grade (MWI Animal Health, Boise, ID). Treatment solutions were sterile-filtered through 0.22- $\mu \mathrm{m}$ membrane filters (Sterivex, Millipore, Billerica, MA) and stored at $4^{\circ} \mathrm{C}$ until the day of infusion. Additionally, $2 \mathrm{~g}$ of ${ }^{13} \mathrm{C}$-labeled AA derived from 
algae ( $\mathrm{U}_{-}{ }^{13} \mathrm{C}, 97$ to $99 \%$ enriched, Cambridge Isotope Laboratories, Andover, MA) were dissolved in $1 \mathrm{~L}$ of $0.9 \%$ saline, sterile-filtered through $0.22-\mu \mathrm{m}$ membrane filters, and jugular infused for $5 \mathrm{~h}$ on d 16 of each period for 1 block of cows $(n=4)$.

On d 8 of each period, cows were fitted with a jugular catheter $(90 \mathrm{~cm} \times 2.03 \mathrm{~mm}$ internal diameter microrenathane, Braintree Scientific Inc., Braintree, MA) for jugular infusion of the treatment solutions. Catheter placement alternated sides by period. Catheters were checked every $4 \mathrm{~h}$ for efficacy and infection at the site of insertion and were removed on $\mathrm{d}$ 18. Treatment and isotope solutions were jugular infused at $135 \mathrm{~mL} / \mathrm{h}$ and $167 \mathrm{~mL} / \mathrm{h}$, respectively, using clinical infusion pumps (model RF-5000, Abott Lifecare, San Antonio, TX). Treatment and isotope solutions bags were gravimetrically weighed before and after infusion. On d 16, at $0800 \mathrm{~h}$, during periods 2 to 4 , cows were fitted with a subcutaneous mammary abdominal vein catheter (13 $\mathrm{cm} \times 14$ gauge, Jorvet, Loveland, CO) for venous sampling, and this catheter was removed on d 16 at $2400 \mathrm{~h}$.

\section{Sample Collection and Analysis}

Milk samples were collected twice daily on d 7 before treatment infusions and then from d 9 to 18 during the treatment infusions at 0100 and $1230 \mathrm{~h}$, stored at $4^{\circ} \mathrm{C}$, and analyzed within $72 \mathrm{~h}$ for fat, true protein, lactose, SCC, and MUN concentrations with a CombiFoss FT

Table 2. Nutrient composition of basal diet (\% of DM)

\begin{tabular}{|c|c|c|}
\hline Item & Mean & $\mathrm{SD}$ \\
\hline $\mathrm{CP}$ & 15.2 & 0.45 \\
\hline $\mathrm{RDP}^{1}$ & 9.98 & - \\
\hline $\mathrm{RUP}^{1}$ & 5.21 & - \\
\hline $\mathrm{NDF}$ & 28.5 & 1.0 \\
\hline $\mathrm{uNDF}^{2}$ & 9.74 & - \\
\hline peNDF $^{3}$ & 18.3 & - \\
\hline Starch & 31.1 & 2.2 \\
\hline Sugar & 4.87 & - \\
\hline Fat & 4.89 & 0.081 \\
\hline PUFA & 2.47 & - \\
\hline $\mathrm{Ca}$ & 0.691 & 0.052 \\
\hline $\mathrm{P}$ & 0.363 & 0.011 \\
\hline $\mathrm{K}$ & 1.36 & 0.073 \\
\hline $\mathrm{Mg}$ & 0.301 & 0.021 \\
\hline $\mathrm{NE}_{\mathrm{L}},{ }^{1} \mathrm{Mcal} / \mathrm{kg}$ & 1.69 & - \\
\hline $\mathrm{NE}_{\mathrm{L}}{ }^{4}{ }^{4} \mathrm{Mcal} / \mathrm{kg}$ & 1.60 & - \\
\hline $\mathrm{MP}^{1} \%$ DM & 9.91 & - \\
\hline
\end{tabular}

${ }^{1}$ Calculated using NDS Professional ration formulation software (version 6.55; RUM\&N, NDS Professional, Reggio nell'Emilia, EmiliaRomagna, Italy) and observed DMI, feed composition, and period average BW.

${ }^{2} \mathrm{uNDF}=$ undigestible NDF.

${ }^{3}$ peNDF $=$ physically effective NDF.

${ }^{4}$ Calculated using NRC (2001) and observed DMI, feed composition, and period average BW.
+ Fourier transform infrared analyzer (Foss Analytics, Hillerød, Denmark) by United DHIA (Radford, VA). On d 16, 1 block of cows $(n=4)$ were frequently milked in their metabolism stalls for measurement of isotope enrichment in milk protein at approximately 1500,1700 , and $1900 \mathrm{~h}$, or 2,4 , and $6 \mathrm{~h}$ relative to the start of the infusion. To ensure complete milk removal, 5 cc of oxytocin was administered intramuscularly. Blood was sampled twice daily, at approximately 0800 and $1800 \mathrm{~h}$, from the coccygeal vein via venipuncture into potassium EDTA and sodium heparin vacutainers (Becton Dickinson, Rutherford, NJ) on d 7, 9, and 12. On d 16, blood was again sampled from the coccygeal vein and the subcutaneous mammary abdominal vein by venipuncture in period 1 and by an indwelling catheter during periods 2 to 4 at approximately 1300, 1500, $1700,1900,2100$, and $2300 \mathrm{~h}$ for 1 block of cows $(\mathrm{n}=$ 6 time points). For the 2nd block of cows, blood was sampled at the additional times of 1330, 1400, 1430, 1600, and 1800 ( $\mathrm{n}=11$ time points) for isotope enrichment of plasma AA. The coccygeal vein sampling was considered arterial (Emery et al., 1965; Hanigan et al., 1991) and will be referenced as arterial blood herein, despite the fact that the blood sampling origin could be arterial or venous. Upon sampling, blood samples were placed on ice and then centrifuged $(<6 \mathrm{~h}$ from first blood sample) at $1,600 \times g$ for $15 \mathrm{~min}$. The resulting plasma was stored in polypropylene tubes at $-20^{\circ} \mathrm{C}$ until further analysis. Tissue samples from the longissimus dorsi and the rear quarter of the udder were biopsied (average $=542 \mathrm{mg}, \mathrm{SD}=139$; Toerien et al., 2010; Daley et al., 2018) on d 18, immediately following the 1230 milking on the tissue biopsy-designated block of cows $(\mathrm{n}=4)$. Biopsies of udder tissue were alternated from the right to left rear quarters and vice versa in successive periods.

Approximately $0.50 \mathrm{~mL}$ of blood plasma were gravimetrically sampled and acid deproteinized using $10 \%$ sulfosalicylic acid and centrifuged at $16,000 \times g$ for $20 \mathrm{~min}$ at $4^{\circ} \mathrm{C}$. The resulting supernatant $(0.25 \mathrm{~mL})$ was gravimetrically combined with a mixture of $\mathrm{U}$ $\left[{ }^{13} \mathrm{C},{ }^{15} \mathrm{~N}\right]$ AA derived from algae (Lot \#16824, Product \#CNLM-452) supplemented with $\left[{ }^{15} \mathrm{~N}_{3}, 99 \%\right.$ enriched] His (Lot \#15858, Product \#NLM-1513), $\left[{ }^{15} \mathrm{~N}, 98 \%\right.$ enriched] Cys (Lot \#14674, Product \#NLM-2295), $\left[{ }^{15} \mathrm{~N}, 99 \%\right.$ enriched] Thr (Lot \#20756, Product \#NLM742), [methyl $-{ }^{13} \mathrm{C}_{3}, 99 \%$ enriched] Met (Lot \#24031, Product \#CLM-206), $\left[\right.$ Amide- ${ }^{15}$ N, 98\% enriched] Asn (Lot \#12319, Product \#NLM-120), and [Amide- ${ }^{15} \mathrm{~N}$, 98\% enriched] Gln (Lot \#15592, Product \#NLM-557) and subsequently desalted via ion chromatography (AG 50W-X8 resin, Bio-Rad Life Science, Hercules, CA). All isotopes were purchased from Cambridge Isotope Laboratories Inc., Tewksbury, MA. Desalted 
samples were freeze-dried, solubilized in acetonitrile (J. T. Baker Inc., Phillipsburg, NJ) and converted to $N$ (tert-butyldimethyl) AA derivatives by incubation for $1 \mathrm{~h}$ at $70^{\circ} \mathrm{C}$ in $N$-methyl- $N$-(tert-butyldimethylsilyl)-trifluoracetamide (Selectra-SIL; UCT Inc., Bristol, PA). The derivatized AA were separated using gas chromatography (Trace GC Ultra; Thermo Fisher Scientific, Waltham, MA) and quantified via mass spectrometry (DSQII; Thermo Fisher Scientific; Calder et al., 1999). Calibration curves for the labeled AA mixture were gravimetrically determined using an AA standard (AAS18; Sigma-Aldrich, St. Louis, MO) supplemented with L-Asn, L-Gln, L-Trp, and L-Cys (Sigma-Aldrich).

\section{Statistical Analysis and Calculations}

Metabolizable protein and EAA supplies were estimated using NDS Professional ration formulation software (version 6.55) and NRC (2001) nutrition models (Table 3 ). Model inputs were based on average dietary nutrient composition (Table 2) and observed least square treatment means of DMI and milk production (Table 4). Efficiency of converting MP and EAA supplies into milk protein were calculated. Metabolizable protein and EAA supplies and maintenance MP requirements were predicted using the NRC (2001) model. Maintenance MP requirements were subtracted from MP supply to yield MP available for lactation. Milk protein yield was then divided by the MP available for lactation to yield a milk protein efficiency from MP for lactation. Metabolizable protein requirements for growth and pregnancy were not considered, as cows did not gain nor lose BW. The EAA profile used for maintenance and milk protein was assumed to be similar. Overall efficiency was also calculated as milk AA yield (g/d) divided by predicted MP-AA supply (g/d). Marginal efficiency was calculated by dividing the difference in milk AA yield for the respective treatment (MKH, IL, or $\left.\mathrm{MKH}^{+} \mathrm{IL}\right)$ compared with $\mathrm{CON}$ by the treatment amount of infused AA. Energy-corrected milk yield was calculated as follows: $\mathrm{ECM}=[(12.86 \times \mathrm{kg}$ of fat $)+(7.04 \times \mathrm{kg}$ of protein $)+(0.3246 \times \mathrm{kg}$ of milk $)]$; NRC (2001). Milk AA output was calculated using true milk protein with a $3.37 \%$ correction for blood-derived proteins and the AA composition of milk protein (Lapierre et al., 2012). Mammary plasma flow (MPF) was estimated using the Fick principle, with Phe and Tyr as the internal markers (Cant et al., 1993). Milk Phe and Tyr yield $(\mu \mathrm{mol} / \mathrm{h})$ were determined from milk protein yield using the average 12 -h period (1300 to $0100 \mathrm{~h}$ ) from d 15 to 17 of each period. Blood arterial and venous Phe and Tyr concentrations were sampled 6 (biopsy block of cows, $\mathrm{n}=4$ ) or 11 times (isotope block of cows, $\mathrm{n}=4$ ) on d 16 from 0130 to $1130 \mathrm{~h}$ and analyzed individually, which should improve precision compared with pooling samples (Lapierre et al., 2012). Net uptake of AA by the mammary gland $(\mu \mathrm{mol} / \mathrm{h})$ was calculated as arterial-venous difference multiplied by MPF. Clearance of AA by the udder was calculated as net uptake divided by venous concentration (Cant et al., 2016).

One cow during period 3 was diagnosed with clinical mastitis, and data for that cow in periods 3 and 4 were discarded. Another cow was diagnosed with clinical mastitis during period 2, and data for only that period were discarded. Data were analyzed with a mixed model using the "Imer" package in $\mathrm{R}$ (version 3.4.3; R Core Team, 2017) for all data except repeated measures data. We used SAS version 9.4 (SAS Institute, Cary, NC. 2010) to examine repeated measures. Milk production, milk composition, and DMI of treatments were analyzed by day, whereas arterial AA, net AA uptake, AA clearance, and ratio of AA uptake to milk protein output were analyzed by experimental period. The following model was used for analyzing data summarized by period:

$$
\begin{aligned}
Y_{i j k l m} & =\mu+M K H_{i}+I L_{j}+M K H^{+} I L_{i j}+\text { Block }_{k} \\
& +\operatorname{Period}_{L}+\operatorname{Cow}(\text { Block })_{m(k)}+e_{i j k l m},
\end{aligned}
$$

where $Y_{i j k l m}=$ the dependent variable, $\mu=$ population mean of $Y, M K H_{i}=$ fixed effect of methionine, lysine, and histidine infusion $(\mathrm{df}=1), I L_{j}=$ fixed effect of isoleucine and leucine infusion ( $\mathrm{df}=1), M K H^{+} I L_{i j}=$ interaction of $M K H_{i}$ and $I L_{j}(\mathrm{df}=1)$, Block $_{k}=$ random effect of block $(\mathrm{df}=1)$, Period $_{L}=$ random effect of period $(\mathrm{df}=3)$, and $\operatorname{Cow}(\text { Block })_{m(k)}=$ random effect of cow nested within block $(\mathrm{df}=6)$. Main effects and interactions were declared significant at $P \leq 0.05$ and trends at $P \leq 0.10$, and denominator degrees of freedom for all tests were adjusted using the Kenward-Roger option. Residual error was evaluated for homogeneity of error and for outliers; if studentized residuals exceeded 3 , the sample was removed from statistical analysis. Post-hoc means-separation testing was conducted only on significant main effects, using the "lsmeansLT" package in $\mathrm{R}$, with degrees of freedom adjusted using the Kenward-Roger option. When the interaction was significant, only the interaction effects were considered during mean-separation tests.

For the data analyzed by day, the following model was constructed using the MIXED procedure of SAS version 9.4 (SAS Institute), which included the previously described model with the addition of repeated fixed effect day (9 df) and all 2-way and 3-way interactions with the other fixed effects. The covariance structure was autoregressive (1) and was selected from the 
available covariance structures using the lowest Bayesian information criterion. When the treatment $\times$ day interaction was significant $(P \leq 0.10)$, the SLICE option was used to determine on which days of the period $(P \leq 0.10)$ treatment means would be separated using Fisher's protected least significant difference test $(P \leq$ $0.10)$. No treatment $\times$ day, 2 -way, or 3 -way interactions were found to be significant $(P>0.20)$ and thus are not reported or discussed. All results reported in this paper are least squares means of the treatment effects, whereas main-effect means are listed in Supplemental Tables S3, S4, S5, S6, S7, and S8 (https://doi.org/10 .3168/jds.2019-17082).

\section{RESULTS AND DISCUSSION}

The objective of this study was to test the hypothesis that multiple EAA can independently increase milk protein yield in lactating dairy cows. The MKH was designed to represent industry and literature recommendations for EAA supplementation, and the resulting treatment achieved ratios and supply balances considered optimal for maximizing milk protein yield (NRC, 2001; Van Amburgh et al., 2015; Table 3; Supplemental Table S2, https://doi.org/ 10.3168/jds.2019-17082). The factorial requirement model of CNCPS (v. 6.55) predicted deficiencies for these EAA ( $-19 \mathrm{~g} / \mathrm{d}$ Met, $-47 \mathrm{~g} / \mathrm{d}$ Lys, and $-6 \mathrm{~g} / \mathrm{d}$ His in CON). The IL objective was to evaluate the hypothesis that signaling properties of these specific EAA could increase milk protein yield. The factorial requirement model of CNCPS (v. 6.55) suggested that these EAA were deficient $(-24 \mathrm{~g} / \mathrm{d}$ of Ile and $-87 \mathrm{~g} / \mathrm{d}$ of Leu in CON), and supplementation with IL reduced this deficiency (Table 3; Supplemental Table S2).

Table 3. Metabolizable protein supplies as predicted by NRC (2001) given observed DMI, infused AA, milk and component yields, and BW, expressed as percentage of metabolizable protein and supply relative to calculated AA requirement

\begin{tabular}{|c|c|c|c|c|}
\hline \multirow[b]{2}{*}{ Item } & \multicolumn{4}{|c|}{ Treatment $^{1}$} \\
\hline & $\mathrm{CON}$ & MKH & IL & $\mathrm{MKH}^{+} \mathrm{IL}$ \\
\hline MP allowable milk, $\mathrm{kg} / \mathrm{d}$ & 37.0 & 38.0 & 39.6 & 39.6 \\
\hline $\mathrm{MP}, \mathrm{g} / \mathrm{d}$ & 2599 & 2704 & 2689 & 2801 \\
\hline $\mathrm{MP}$ balance, $\mathrm{g} / \mathrm{d}$ & -478 & -468 & -451 & -513 \\
\hline RDP balance, $\mathrm{g} / \mathrm{d}$ & -25 & -23 & -22 & -23 \\
\hline RUP balance, g/d & -574 & -656 & -680 & -797 \\
\hline \multicolumn{5}{|l|}{ Histidine } \\
\hline Calculated requirement, ${ }^{2} \mathrm{~g} / \mathrm{d}$ & 68 & 70 & 69 & 73 \\
\hline Diet supply, g/d & 57 & 57 & 57 & 58 \\
\hline Jugular infusion, g/d & 0 & 20 & 0 & 20 \\
\hline Balance, $\mathrm{g} / \mathrm{d}$ & -11 & 7 & -12 & 5 \\
\hline Percent of MP & 2.19 & 2.85 & 2.12 & 2.78 \\
\hline \multicolumn{5}{|l|}{ Isoleucine } \\
\hline Diet supply, $\mathrm{g} / \mathrm{d}$ & 126 & 127 & 127 & 128 \\
\hline Jugular infusion, g/d & 0 & 0 & 22 & 22 \\
\hline Percent of MP & 4.85 & 4.70 & 5.54 & 5.36 \\
\hline \multicolumn{5}{|l|}{ Leucine } \\
\hline Diet supply, g/d & 231 & 233 & 233 & 236 \\
\hline Jugular infusion, g/d & 0 & 0 & 50 & 50 \\
\hline Percent of MP & 8.89 & 8.62 & 10.52 & 10.21 \\
\hline \multicolumn{5}{|l|}{ Lysine } \\
\hline Calculated requirement, ${ }^{2} \mathrm{~g} / \mathrm{d}$ & 203 & 209 & 207 & 219 \\
\hline Diet supply, g/d & 166 & 168 & 168 & 169 \\
\hline Jugular infusion, g/d & 0 & 38 & 0 & 38 \\
\hline Balance, $g / d$ & -37 & -3 & -39 & -12 \\
\hline Percent of MP & 6.39 & 7.62 & 6.25 & 7.39 \\
\hline \multicolumn{5}{|l|}{ Methionine } \\
\hline Calculated requirement, ${ }^{2} \mathrm{~g} / \mathrm{d}$ & 68 & 70 & 69 & 73 \\
\hline Diet supply, g/d & 49 & 49 & 49 & 50 \\
\hline Jugular infusion, g/d & 0 & 21 & 0 & 21 \\
\hline Balance, $g / d$ & -19 & 0 & -20 & -2 \\
\hline Percent of MP & 1.89 & 2.59 & 1.82 & 2.53 \\
\hline
\end{tabular}

${ }^{1} \mathrm{CON}=$ infused $3 \mathrm{~L}$ of $0.9 \%$ saline; $\mathrm{MKH}=$ infused $21 \mathrm{~g} / \mathrm{d}$ of Met, $20 \mathrm{~g} / \mathrm{d}$ of His, and $38 \mathrm{~g} / \mathrm{d}$ of Lys; IL $=$ infused $22 \mathrm{~g} / \mathrm{d}$ of Ile and $50 \mathrm{~g} / \mathrm{d}$ of Leu; MKH ${ }^{+} \mathrm{IL}=$ infused $21 \mathrm{~g} / \mathrm{d}$ of Met, $20 \mathrm{~g} / \mathrm{d}$ of His, $38 \mathrm{~g} / \mathrm{d}$ of Lys, 22 $\mathrm{g} / \mathrm{d}$ of Ile, and $50 \mathrm{~g} / \mathrm{d}$ of Leu.

${ }^{2}$ Calculated requirements for His, Lys, and Met were assessed as 2.2, 6.6, and 2.2\%, respectively, of MP requirements. 
Cows in second lactation were selected, to minimize the issue of leaky external pudic vein valves, which involves nonmammary blood entering the subcutaneous abdominal venous blood drainage of mammary tissue (Bequette et al., 1999). This issue becomes more prevalent in older cows - that is, third lactation and higher (Bequette et al., 1999). To avoid any uncertainty with respect to the bioavailability of ruminally protected AA, the supplemented AA were provided by jugular infusion (Vyas and Erdman, 2009). Additionally, jugular infusion eliminates uncertainty regarding digestion and gastrointestinal metabolism of AA when supplying AA via post-ruminal infusions. Gastrointestinal metabolism has been demonstrated to vary by individual amino acid (Hanigan et al., 2004; Estes et al., 2018). Feeding rumen-protected AA instead of jugular infusion may result in slightly different results than those obtained herein. The NRC (2001) does not account for gastrointestinal catabolism varying by EAA, only for catabolism of the aggregate; therefore, even if we formulated for metabolizable supplies of the treatment EAA, supplies available for metabolism would have been slightly different.

\section{Experimental Diet and Nutrient Supply}

Composition of the basal diet is provided in Table 1 , and nutrient composition of forages and major in- gredients are listed in Supplemental Table S1 (https: //doi.org/10.3168/jds.2019-17082). Dietary mixing variation was greater than expected for corn grain, which resulted in a $21.9 \%$ coefficient of variation on a diet DM basis (Table 1). This was primarily due to an employee ingredient-loading accuracy issue. The mixing variation affected all treatments similarly. This mixing variation could be considered problematic by some; however, experiments with high-producing cows that were subjected to extreme dietary variation have shown no major effects on cow performance (McBeth et al., 2013; Yoder et al., 2013).

Dietary nutrient concentrations are listed in Table 2. Predicted protein and AA supplies by the NRC 2001 are provided in Table 3, and predictions by CNCPS (v. 6.55) are listed in Supplemental Table S2 (https: //doi.org/10.3168/jds.2019-17082). The experimental diet was nearly adequate in rumen-degradable protein (NRC, 2001), which achieved our objective of not hindering ruminal nutrient digestion or intake (Table $3)$. The MP deficit predicted by the NRC (2001) and CNCPS (v. 6.55) models was 14 to $15 \%$, or 10 to $11 \mathrm{~kg}$ of milk, for all treatments (Table 3; Supplemental Table S2). The underprediction might reflect inaccurate supply estimates, particularly microbial protein, protein mobilization from body stores, maintenance requirement overestimation, or error in the marginal efficiency of metabolizable protein conversion to milk protein.

Table 4. Effect of AA infusions on intake, milk production parameters, nutrient efficiency, and BW (least-square treatment means)

\begin{tabular}{|c|c|c|c|c|c|c|c|c|}
\hline \multirow[b]{2}{*}{ Item } & \multicolumn{4}{|c|}{ Treatment $^{1}$} & \multirow[b]{2}{*}{ SEM } & \multicolumn{3}{|c|}{ Effect ( $P$-value $)$} \\
\hline & $\mathrm{CON}$ & $\mathrm{MKH}$ & IL & $\mathrm{MKH}^{+} \mathrm{IL}$ & & $\mathrm{MKH}$ & IL & $\mathrm{MKH} \times \mathrm{IL}$ \\
\hline DMI, $\mathrm{kg} / \mathrm{d}$ & 25.3 & 25.6 & 25.5 & 25.8 & 0.41 & 0.45 & 0.31 & 0.90 \\
\hline Dietary CP, kg/d & 3.85 & 3.87 & 3.88 & 3.92 & 0.06 & 0.45 & 0.31 & 0.90 \\
\hline Infused AA, g/d & 0 & 78.9 & 71.9 & 150.8 & 0.04 & $<0.001$ & $<0.001$ & 0.53 \\
\hline Total CP, kg/d & 3.85 & 3.96 & 3.95 & 4.06 & 0.06 & 0.01 & 0.01 & 0.99 \\
\hline $\mathrm{ECM},{ }^{2} \mathrm{~kg} / \mathrm{d}$ & 47.2 & 48.3 & 49.1 & 50.1 & 1.03 & 0.14 & $<0.01$ & 0.93 \\
\hline Milk protein \% & 3.10 & 3.19 & 3.04 & 3.21 & 0.04 & $<0.001$ & 0.45 & 0.09 \\
\hline Milk protein, $\mathrm{g} / \mathrm{d}$ & 1,458 & 1,517 & 1,498 & 1,603 & 32 & $<0.001$ & $<0.01$ & 0.28 \\
\hline Milk fat $\%$ & 3.58 & 3.55 & 3.55 & 3.42 & 0.11 & 0.29 & 0.28 & 0.48 \\
\hline Milk fat, $\mathrm{g} / \mathrm{d}$ & 1,675 & 1,716 & 1,744 & 1,741 & 56 & 0.60 & 0.22 & 0.56 \\
\hline Lactose, \% & 5.04 & 4.99 & 5.05 & 4.97 & 0.03 & $<0.001$ & 0.67 & 0.48 \\
\hline Lactose, $\mathrm{g} / \mathrm{d}$ & 2,389 & 2,388 & 2,505 & 2,508 & 53 & 0.98 & $<0.01$ & 0.97 \\
\hline BW change, $\mathrm{kg} /$ period & -13.2 & -13.5 & -14.0 & -8.46 & 9.94 & 0.69 & 0.76 & 0.66 \\
\hline
\end{tabular}

${ }^{1} \mathrm{CON}=$ infused $3 \mathrm{~L}$ of $0.9 \%$ saline; MKH = infused $21 \mathrm{~g} / \mathrm{d}$ of Met, $20 \mathrm{~g} / \mathrm{d}$ of His, and $38 \mathrm{~g} / \mathrm{d}$ of Lys; IL = infused $22 \mathrm{~g} / \mathrm{d}$ of Ile and $50 \mathrm{~g} / \mathrm{d}$ of Leu; $\mathrm{MKH}^{+} \mathrm{IL}=$ infused $21 \mathrm{~g} / \mathrm{d}$ of Met, $20 \mathrm{~g} / \mathrm{d}$ of His, $38 \mathrm{~g} / \mathrm{d}$ of Lys, $22 \mathrm{~g} / \mathrm{d}$ of Ile, and $50 \mathrm{~g} / \mathrm{d}$ of Leu.

${ }^{2} \mathrm{ECM}$ calculated as $(12.82 \times \mathrm{kg}$ of fat $)+(7.13 \times \mathrm{kg}$ of protein $)+(0.323 \times \mathrm{kg}$ of milk $)$.

${ }^{3}$ Protein efficiency calculated as milk protein yield $(\mathrm{kg} / \mathrm{d}) /$ total $\mathrm{CP}$ intake $(\mathrm{kg} / \mathrm{d})$.

${ }^{4} \mathrm{GFE}=$ gross feed efficiency, calculated as ECM yield $(\mathrm{kg} / \mathrm{d}) / \mathrm{DMI}(\mathrm{kg} / \mathrm{d})$. 
Model underprediction of protein-allowable milk at levels similar to those found in this study (approximately $11 \mathrm{~kg}$ of milk) has previously been observed (Doelman et al., 2015a,b; Doepel et al., 2016), but not at the level of milk production in this study, which averaged $48.7 \mathrm{~kg} / \mathrm{d}$, approximately $20 \mathrm{~kg} / \mathrm{d}$ higher than the mentioned studies. Metabolizable supplies of Met, Lys, and $\mathrm{His}$ for $\mathrm{CON}$ were below calculated requirements (NRC, 2001; Table 3) and less than optimal supplies relative to metabolizable energy (CNCPS v. 6.55; Table 3; Supplemental Table S2). Metabolizable Ile and Leu for CON deficits were 16 and $31 \%$ of requirements, according to CNCPS v. 6.55 (Supplemental Table S2).

\section{Intake}

Dry matter and dietary CP intakes were not affected by treatment (Table 4). The jugular treatment infusions increased total $\mathrm{CP}$ intake for $\mathrm{MKH}(P=0.01)$ and IL $(P=0.01)$, with no interaction of the main effects. Histidine supplementation has previously been shown to increase feed intake (Lee et al., 2012; Giallongo et al., 2017), whereas methionine supplementation, if excessive, can decrease intake (Satter et al., 1975; Robinson et al., 2000). Numerically, intake increased in response to $\mathrm{MKH}$, but counteracting effects of potentially excess Met may have negated any benefit from His supplementation. Another potential reason for the lack of a DMI response to supplemental His is that the trial was short-term (18-d periods), as His deficiency takes several weeks to occur due to mobilization from plasma hemoglobin and muscle carnosine (Lapierre et al., 2008; Lee et al., 2012). This may have buffered His deficiency in this trial. Infusions of Ile and Leu were not expected to change intake, given previous findings (Korhonen et al., 2002; Weekes et al., 2006; Appuhamy et al., 2011).

\section{Milk Components}

Milk component concentrations and yields are shown in Table 4 and Supplemental Figure S1 (https://doi .org/10.3168/jds.2019-17082). Milk protein yield increased by 5.5 and $4.3 \%$ for MKH $(P<0.01)$ and IL $(P$ $<0.01$ ), respectively (Table 4$)$. Milk protein concentration increased for MKH $(P<0.01)$ but was unchanged for IL (Table 4). We found no interaction between $\mathrm{MKH}$ and IL, indicating that milk protein yield can be stimulated independently and additively by EAA. The milk protein yield increase from provision of additional Met, Lys, and His supplementation was expected (Lee et al., 2012; Giallongo et al., 2017). The increase in milk protein yield by IL independent of MKH agrees with in vitro findings (Appuhamy et al., 2012; Arriola Apelo et al., 2014c) but disagrees with previous in vivo trials (Huhtanen et al., 2002; Appuhamy et al., 2011; Arriola Apelo et al., 2014a). The observation also disagrees with the hypothesis that the maximal milk protein yield is capped solely by a single first-limiting EAA. Methionine, Lys, or His were, as a group, limiting EAA, given the observed positive response herein; however, despite this limitation, milk protein yield also increased with Ile and Leu supplementation (Table 4).

Regarding the other milk components, we found no treatment effect on milk fat yield or concentration (Table 4). Lactose concentration was decreased for $\mathrm{MKH}$ $(P<0.01)$ and unchanged by IL (Table 4$)$. Lactose yield was increased for IL $(P<0.01)$ but unchanged by MKH (Table 4). Milk fat yield is usually not affected by supplementation of the classical limiting EAA, Met, Lys, and His, either as a group or individually (Appuhamy et al., 2011; Lee et al., 2012). The increase in lactose yield for IL correlates with the increased milk yield observed for IL.

\section{Milk Yield}

Milk production is shown in Table 4 and Supplemental Figure S1. The IL treatment increased milk and ECM yields by $2.3(P<0.01)$ and $1.9 \mathrm{~kg} / \mathrm{d}(P=0.01)$, respectively. No effect was observed for MKH or for the interaction (Table 4). Increased milk or ECM yields from supplementation of Ile or Leu have not been previously observed (Korhonen et al., 2002; Arriola Apelo et al., 2014a; Doelman et al., 2015b). However, a recent meta-analysis $(\mathrm{n}=258$ treatment means) indicated positive milk yield responses to Leu (Lean et al., 2018). Based on that meta-regression equation, the change in milk yield from CON to IL was predicted to be 1.5 $\mathrm{kg} / \mathrm{d}$, which was close to the observed response. Decreased activation of the mTORC1 pathway when Leu and Ile are deficient has been observed for both in vitro and in some in vivo studies (Arriola Apelo et al., 2014b; Doelman et al., 2015b; Liu et al., 2017). Decreased mTORC1 activation due to Leu and Ile deficiency might lead to decreased mammary tissue anabolic activity and milk protein yield. The increased protein yield observed with IL treatment $(P<0.01)$ may have increased $\alpha$-lactalbumin, thereby driving the lactose disaccharide formation of galactose and glucose via allosteric activation of galactosyl transferase. Increased lactose yield propels greater milk yield. However, this latter theory of protein yield driving milk yield did not occur for MKH, only for IL. 
The increased milk and protein yield for IL differ from previous studies. Given the complexity of mTOR regulation, perhaps the variations in cow responses to Ile and Leu supplementation are not surprising. The anabolic signaling of mTORC1 is regulated by a multitude of factors, including oxygen, glucose, AA, energy, and insulin (Sabatini, 2017), as well as being inhibited by the integrated stress pathway via ATF4 - that is, amino acid and glucose deficiency, endoplasmic reticulum stress (unfolded proteins), and oxidative stress (Baird and Wek, 2012; Wolfson and Sabatini, 2017). Hence, variation in cow responses to the strategy of manipulating mTORC1 seems likely. Intracellular Leu and, to a lesser extent, Ile bind to Sestrin2 triggering GATOR2 to activate mTORC1, which then phosphorylates key initiation factors controlling rates of translation and protein synthesis (Saxton et al., 2016; Wolfson et al., 2016). Activation of mTORC1 by Leu or Ile can be inhibited by Sestrin 2 concentrations. For example, high levels of Sestrin2 expression can completely blunt Leu activation despite increasing Leu intracellular concentrations (Wolfson and Sabatini, 2017). Sestrin2 expression is regulated by the transcription factor ATF4, and activation of this transcription factor can arise from a variety of factors, including long-term AA starvation and endoplasmic reticulum stress via phosphorylation of eIF2a (Baird and Wek, 2012). Milk fat depression via trans-10,cis-12 conjugated linoleic acid causes endoplasmic reticulum stress and inhibition of SREBP1 in mouse adipocytes, which have been shown to be related to phosphorylation of eIF2a and increased expression of ATF4 (LaRosa et al., 2007). Hence, although the link is speculative, severe milk fat depression might block anabolic activation of mTORC1 via Sestrin2. In 2 previous studies (Appuhamy et al., 2011; Arriola Apelo et al., 2014a), BCAA or individual Leu supplementation failed to increase milk protein yield, but in those studies the average treatment milk fat concentrations were $2.46 \%$ and $3.07 \%$, both indicative of severe milk fat depression (Bauman et al., 2011). Additionally, milk fat depression (2.86 and $2.82 \%$ ) as well as very low CP diets (11.2\% DM, $12.4 \% \mathrm{DM})$, coupled with relatively low milk production given DIM $(30.1 \mathrm{~kg} / \mathrm{d}$ at $105 \mathrm{DIM}$ and $33.9 \mathrm{~kg} / \mathrm{d}$ at $78 \mathrm{DIM})$ in 2 recent studies that evaluated $\mathrm{mTORC} 1$ signaling, may explain the lack of mTORC1 signaling responses to the subtraction or provision of Leu (Doelman et al., 2015b; Nichols et al., 2017). In summary, other factors might block the effects of supplementing translation stimulatory EAA (e.g., Leu, Ile), thereby imposing multivariate complexity on inference.

The lack of response to MKH in milk and ECM yields is consistent with some studies, particularly short-term studies and meta-analyses (Appuhamy et al., 2011; Sin- clair et al., 2014; Zanton et al., 2014) but inconsistent with others (Noftsger and St-Pierre, 2003; St-Pierre and Sylvester, 2005). The mechanism for mTORC1 activation by Lys or His appears to be less potent or nonexistent compared with Ile and Leu (Appuhamy et al., 2012). Methionine does activate mTORC1 via Sestrin2 binding, although with much lower affinity than leucine (Wolfson et al., 2016) or via SAMTOR via 1-carbon metabolism (Gu et al., 2017). Another reason for the lack of milk and ECM responses to MKH is that these EAA are perhaps not as deficient or limiting as nutrition models would imply (NRC, 2001). Hence, the modest response to $\mathrm{MKH}$ in milk protein yield and concentration might reflect that these EAA were not significantly deficient.

\section{Efficiency}

Nutrient efficiency, MUN, and BW measurements are shown in Table 4. Body weight change and ending weights were unaffected. Gross feed efficiency tended to increase $(+3.2 \%)$ with IL $(P=0.07)$. Greater partitioning of nutrients to mammary gland or enhanced anabolic activity of the udder (e.g., rBST supplementation) have been observed to increase feed efficiency. If our hypothesis is accurate and IL promotes more anabolic activity, then the latter may explain the increase in gross feed efficiency. Nitrogen efficiency also tended to increase for MKH $(P=0.09)$, and the difference is observed in the main-effect treatment means (Supplemental Table S3, https://doi.org/10.3168/jds .2019-17082). Overall, the average N efficiency across treatments was $38.5 \%$, which is substantially higher than the average efficiency of $25 \%$ for lower-producing lactating dairy cows fed conventional diets (Hristov et al., 2004) but similar to the results of a previous jugular infusion trial (Appuhamy et al., 2011). Milk urea nitrogen was unaffected and below typical concentrations, indicative of high $\mathrm{N}$ efficiency, averaging $8.44 \mathrm{mg} / \mathrm{dL}$. The lack of treatment effects on MUN suggests that the increased $\mathrm{N}$ intake $(P<0.01)$ from the infusions likely offset the gain in milk protein yield and reduced catabolism of AA that were not infused. This has also been found in previous studies (Appuhamy et al., 2011; Lee et al., 2012; Giallongo et al., 2016).

\section{Arterial Plasma AA}

The arterial plasma AA concentrations are shown in Table 5. The infused EAA all increased as expected $(P<0.03$; Table 5, Supplemental Figures S2 and S3, https://doi.org/10.3168/jds.2019-17082). This differs from the results of some previous jugular infusion trials, in which Leu and Ile concentrations did not in- 
crease in response to Leu and Ile infusions (Appuhamy et al., 2011; Kassube et al., 2017). Total AA, EAA, and NEAA arterial concentrations were unaffected. Individually, Leu $(P=0.03)$, Phe $(P<0.01)$, Thr $(P$ $<0.01)$, and Val $(P=0.06)$ all declined or tended to decline in arterial concentration in response to $\mathrm{MKH}$, which was likely driven by increased demand by mammary tissue in support of greater milk protein yield. For IL, only Val declined $(P=0.06)$, and this was likely also driven by increased demand by mammary tissue. Previously, jugular infusions of Met and Lys increased milk protein yield but did not contribute to a decline in plasma concentrations of other EAA except for Ile (Appuhamy et al., 2011; Kassube et al., 2017). However, dietary CP (16.0\%) and MUN (12.5 mg/dL) were much higher for these prior studies than for this study, which may have buffered changes in the concentrations of those other EAA.

For NEAA, Gly $(P=0.02)$, Ser $(P=0.12)$, and Tyr $(P<0.01)$ arterial plasma concentrations decreased for $\mathrm{MKH}$, and none were changed individually for IL. This is not usually observed with cows supplemented with Met, Lys, and His (Lee et al., 2012; Giallongo et al., 2016); however, the high level of protein yield, coupled with a $14 \%$ deficit in MP in this experiment, might result in a limited supply of AA in general-hence the drawdown of Gly, Ser, and Tyr. The Tyr venous concentration fell $81 \%$ in response to MKH (Supplemental Table S5, https://doi.org/10.3168/jds.2019-17082). Minimal synthesis of Tyr from Phe occurs in the mammary gland, observed to be 3 to $5 \%$ in lactating goats (Bequette et al., 1999), so increased protein yield likely drove much greater extraction of Tyr from the arterial blood.

\section{Mammary Uptake of AA}

Mammary plasma flow and net AA uptake by the udder are shown in Table 6. Mammary plasma flow increased by $24 \%(P=0.01)$ in response to IL, whereas plasma flow numerically decreased by $9.5 \%(P=0.22)$ for MKH. Mammary plasma flow is highly correlated

Table 5. Arterial AA plasma concentrations, $\mu M$ (least squares treatment means) $^{1}$

\begin{tabular}{|c|c|c|c|c|c|c|c|c|}
\hline \multirow[b]{2}{*}{ Item } & \multicolumn{4}{|c|}{ Treatment $^{2}$} & \multirow[b]{2}{*}{ SEM } & \multicolumn{3}{|c|}{ Effect ( $P$-value) } \\
\hline & $\mathrm{CON}$ & MKH & IL & $\mathrm{MKH}^{+} \mathrm{IL}$ & & MKH & IL & $\mathrm{MKH} \times \mathrm{IL}$ \\
\hline Arg & 80.8 & 87.6 & 81.8 & 83.7 & 4.6 & 0.20 & 0.66 & 0.45 \\
\hline His & 64.7 & 84.8 & 63.4 & 84.0 & 3.0 & $<0.001$ & 0.65 & 0.93 \\
\hline Ile & 127.3 & 137.1 & 158.2 & 136.3 & 9.6 & 0.32 & 0.02 & 0.02 \\
\hline Leu & 201.2 & 189.1 & 267.8 & 239.3 & 16.9 & 0.03 & $<0.001$ & 0.33 \\
\hline Lys & 85.2 & 121.4 & 87.6 & 109.6 & 5.9 & $<0.001$ & 0.20 & 0.05 \\
\hline Met & 23.6 & 45.9 & 23.6 & 43.4 & 2.2 & $<0.001$ & 0.52 & 0.52 \\
\hline Phe & 46.2 & 44.5 & 48.2 & 42.5 & 2.0 & $<0.01$ & 0.98 & 0.11 \\
\hline Thr & 99.0 & 89.0 & 95.4 & 83.2 & 4.9 & $<0.001$ & 0.10 & 0.69 \\
\hline Val & 285.6 & 269.5 & 263.9 & 231.8 & 22.2 & 0.06 & 0.03 & 0.51 \\
\hline Ala & 265.9 & 270.8 & 270.7 & 271.4 & 20.5 & 0.76 & 0.78 & 0.82 \\
\hline Asn & 22.9 & 23.0 & 23.3 & 21.4 & 2.2 & 0.53 & 0.68 & 0.48 \\
\hline Asp & 13.8 & 14.3 & 13.0 & 13.5 & 1.4 & 0.59 & 0.43 & 0.98 \\
\hline Gln & 146.0 & 143.3 & 152.0 & 146.1 & 11.1 & 0.23 & 0.23 & 0.65 \\
\hline Glu & 109.9 & 104.8 & 106.3 & 108.4 & 9.5 & 0.68 & 0.99 & 0.31 \\
\hline Gly & 291.8 & 252.0 & 280.3 & 257.0 & 31.7 & 0.02 & 0.79 & 0.49 \\
\hline Pro & 108.6 & 109.3 & 109.0 & 110.3 & 5.6 & 0.77 & 0.83 & 0.92 \\
\hline Ser & 90.4 & 84.9 & 91.7 & 84.3 & 6.5 & 0.12 & 0.93 & 0.797 \\
\hline Tyr & 35.4 & 31.8 & 35.3 & 27.9 & 2.7 & $<0.01$ & 0.22 & 0.24 \\
\hline $\mathrm{TAA}^{3}$ & 2,103 & 2,109 & 2,167 & 2,115 & 57.8 & 0.61 & 0.45 & 0.53 \\
\hline $\mathrm{EAA}^{4}$ & 1,023 & 1,078 & 1,087 & 1,060 & 55.8 & 0.67 & 0.50 & 0.21 \\
\hline $\mathrm{BCAA}^{5}$ & 623 & 596 & 688 & 608 & 48.8 & 0.06 & 0.18 & 0.34 \\
\hline EAA-MKH ${ }^{6}$ & 849 & 817 & 912 & 817 & 50.8 & 0.05 & 0.32 & 0.30 \\
\hline $\mathrm{EAA} \mathrm{IL}^{7}$ & 685 & 749 & 664 & 682 & 29.5 & 0.03 & 0.02 & 0.21 \\
\hline NEAA $^{8}$ & 1,089 & 1,041 & 1,080 & 1,046 & 54.5 & 0.19 & 0.95 & 0.81 \\
\hline
\end{tabular}

${ }^{1}$ Data represent average AA concentrations sampled from the coccygeal vessels for d 9, 12, and 16 of the experimental period.

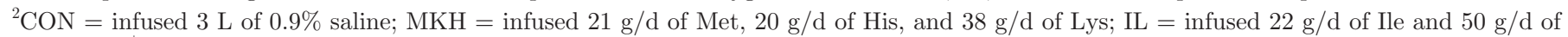
$\mathrm{Leu} ; \mathrm{MKH}^{+} \mathrm{IL}=$ infused $21 \mathrm{~g} / \mathrm{d}$ of Met, $20 \mathrm{~g} / \mathrm{d}$ of His, $38 \mathrm{~g} / \mathrm{d}$ of Lys, $22 \mathrm{~g} / \mathrm{d}$ of Ile, and $50 \mathrm{~g} / \mathrm{d}$ of Leu.

${ }^{3} \mathrm{TAA}=$ total AA $(\mathrm{EAA}+\mathrm{NEAA})$.

${ }^{4} \mathrm{EAA}=$ Arg, His, Ile, Leu, Lys, Met, Phe, Thr, and Val.

${ }^{5} \mathrm{BCAA}=$ branched-chain AA: Ile, Leu, and Val.

${ }^{6} \mathrm{EAA}-\mathrm{MKH}=\mathrm{Arg}$, Ile, Leu, Phe, Thr, and Val.

${ }^{7} \mathrm{EAA}-\mathrm{IL}=$ Arg, His, Lys, Met, Phe, Thr, and Val.

${ }^{8} \mathrm{NEAA}=$ Ala, Asn, Asp, Gln, Glu, Gly, Pro, Ser, and Tyr. 
Table 6. Mammary plasma flow (MPF) and net uptake of AA (least squares treatment means) ${ }^{1}$

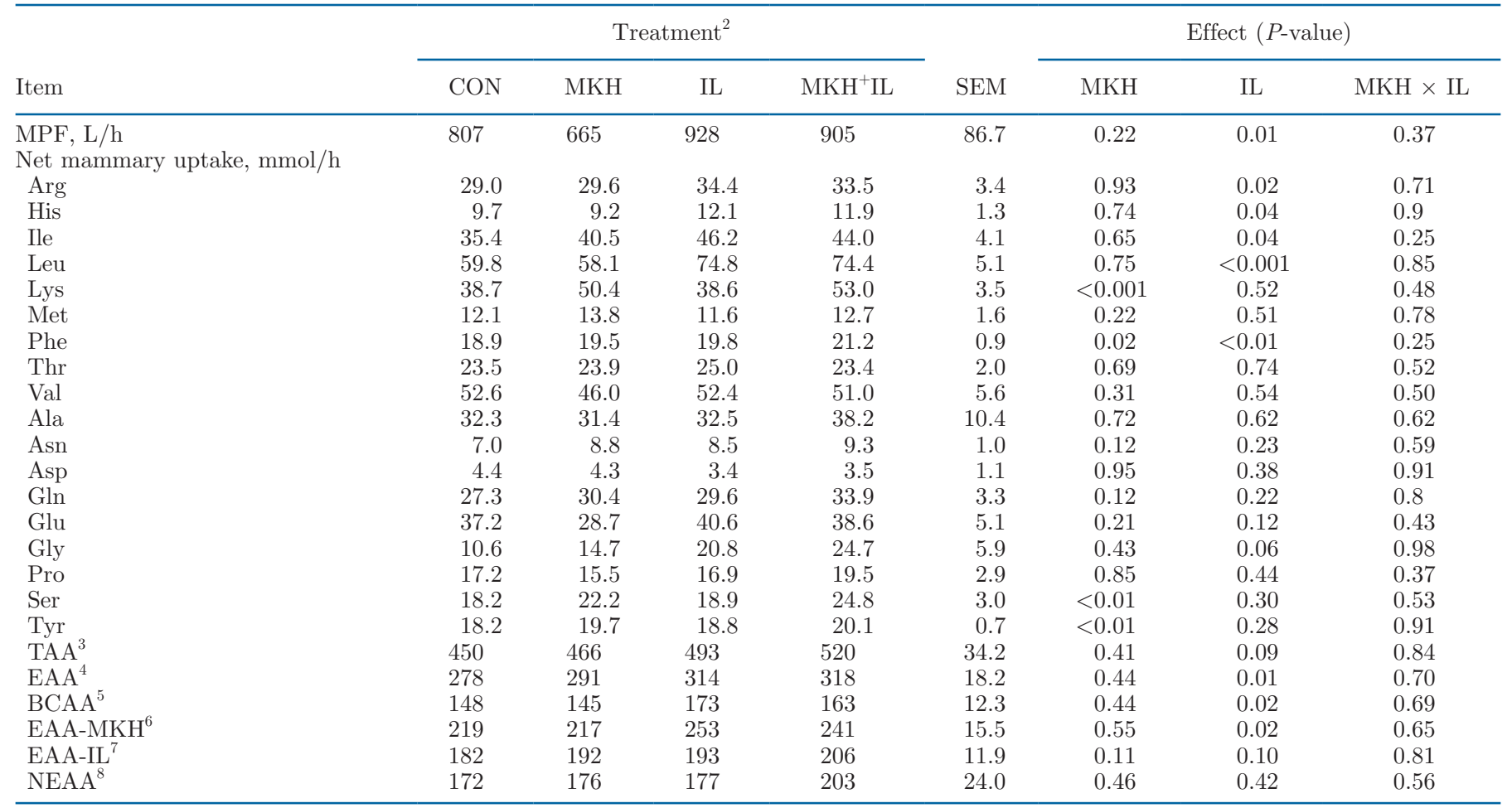

${ }^{1}$ Data represent arterial and venous measurements $(\mathrm{n}=6$ to 11 samples per cow $)$ taken on $\mathrm{d} 16$.

${ }^{2} \mathrm{CON}=$ infused $3 \mathrm{~L}$ of $0.9 \%$ saline; $\mathrm{MKH}=$ infused $21 \mathrm{~g} / \mathrm{d}$ of Met, $20 \mathrm{~g} / \mathrm{d}$ of His, and $38 \mathrm{~g} / \mathrm{d}$ of Lys; IL = infused $22 \mathrm{~g} / \mathrm{d}$ of Ile and $50 \mathrm{~g} / \mathrm{d}$ of Leu; MKH ${ }^{+} \mathrm{IL}=$ infused $21 \mathrm{~g} / \mathrm{d}$ of Met, $20 \mathrm{~g} / \mathrm{d}$ of His, $38 \mathrm{~g} / \mathrm{d}$ of Lys, $22 \mathrm{~g} / \mathrm{d}$ of Ile, and $50 \mathrm{~g} / \mathrm{d}$ of Leu.

${ }^{3} \mathrm{TAA}=$ total $\mathrm{AA}(\mathrm{EAA}+\mathrm{NEAA})$.

${ }^{4} \mathrm{EAA}=$ Arg, His, Ile, Leu, Lys, Met, Phe, Thr, and Val.

${ }^{5} \mathrm{BCAA}=$ branched-chain AA: Ile, Leu, and Val.

${ }^{6} \mathrm{EAA}-\mathrm{MKH}=\mathrm{Arg}$, Ile, Leu, Phe, Thr, and Val.

${ }^{7} \mathrm{EAA}-\mathrm{IL}=$ Arg, His, Lys, Met, Phe, Thr, and Val.

${ }^{8} \mathrm{NEAA}=$ Ala, Asn, Asp, Gln, Glu, Gly, Pro, Ser, and Tyr.

with milk yield (Prosser et al., 1996); hence, the 2.3 $\mathrm{kg} / \mathrm{d}$ milk yield response to IL correlates with increased MPF. Two potential reasons for the increased MPF exist: (1) greater anabolic activity associated with stimulation of mTORC1 that results in ADP buildup and release into the interstitium, which triggers nitric oxide synthesis from arginine (Cieslar et al., 2014), or (2) a shortage of 1 or more individual EAA (Cant et al., 2018), acting through an unknown mechanism. Using the regression equation of Purdie et al. (2009), MPF was predicted to increase by $111 \mathrm{~L} / \mathrm{h}$ for the IL treatment, given the observed milk yield change. The observed increase was $180 \mathrm{~L} / \mathrm{h}$. Plasma flow stimulation has been observed in response to deficiencies in His, Lys, and Thr (Bequette et al., 2000; Doepel et al., 2016; Guo et al., 2017). This appears to be a mechanism to maintain an adequate supply of nutrients to the udder for maintenance of milk production even under deficient conditions. Clearly MKH and IL stimu- lated mammary activity, which may have altered ADP concentrations. Plasma Thr concentrations also tended to decline $(P=0.10)$, which may have been the trigger for a local MPF response. Whether the change in MPF was caused by increased metabolism or by shortage of an EAA remains to be elucidated. However, this study demonstrated the plasticity of the mammary gland to facilitate increased milk protein yield without supplementation of the classic limiting EAA.

Net uptake of several EAA increased in response to the treatments likely to support greater protein yield (Table 6). Amino acid substrates for greater yield must originate from either reduced catabolism or accretion of protein in the mammary gland or from greater uptake from arterial blood. Despite the 9.5\% numerical decline in MPF in response to $\mathrm{MKH}$, increased net uptake of Lys $(P<0.01)$, Phe $(P=0.02)$, Asn $(P=0.12)$, Gln $(P$ $=0.12)$, Ser $(P<0.01)$, and Tyr $(P<0.01)$ occurred. Venous concentration of Lys increased $32 \%(P<0.01)$ 
in response to MKH (Supplemental Table S5, https:// doi.org/10.3168/jds.2019-17082), which led to net udder uptake increasing by $32 \%(P<0.01$; Supplemental Table S6, https://doi.org/10.3168/jds.2019-17082). The Lys uptake-to-output ratio increased from 1.05 to 1.32 for MKH (Supplemental Table S7, https://doi .org/10.3168/jds.2019-17082), and the marginal transfer efficiency of the extra Lys into milk protein Lys was only $13 \%$. The nitrogen in Lys can be used for synthesis of Gln, Glu, Asp, Asn, Ser, and Ala (Lapierre et al., 2009). It has been shown that Lys net uptake to milk protein output ratios approaching 1 result in reduced milk protein yield (Lapierre et al., 2009; Guo et al., 2017). Thus, some Lys catabolism is apparently obligatory, and one cannot assume that all EAA with uptaketo-output ratios greater than 1 are not deficient. Uptake of Phe and Tyr increased for MKH (5.2 and 7.6\%, respectively), which closely matched the milk protein response of $5.5 \%$. Methionine uptake numerically increased by $12.7 \%(P=0.22)$, which is greater than the milk protein response for MKH. Histidine net uptake was unchanged $(P=0.74)$, as was the net uptake-tooutput ratio $(P=0.54)$ for MKH. Histidine is unique in that a significant portion of His supply can originate from peptides (carnosine, anserine; Lapierre et al., 2008). Plasma His could have been used by muscle to synthesize these peptides, and the peptides released to plasma for use by mammary tissue to synthesize milk protein (Lapierre et al., 2012). Histidine catabolism by mammary tissue could also have been reduced. The latter should be reflected in uptake-to-output ratios, but His is subject to greater analytical variation (Lapierre et al., 2012). The increase or numerical increase in net uptake of the other NEAA for MKH - that is, Ser $(P$ $<0.01)$, Asn $(P=0.12)$, and Gln $(P=0.12)$ - might reflect the increased demand to match the milk protein response or diminished catabolism of EAA for synthesis of NEAA due to reduction in EAA availability. For example, Arg and BCAA net uptake did not change for $\mathrm{MKH}$, and these EAA serve as precursors for Gln, Ser, and Asn (Roets et al., 1979, 1983; Rubert-Alemán et al., 1999). The uptake-to-output ratios of Leu $(P=$ $0.14)$ and $\operatorname{Val}(P=0.10)$ tended to decline, indicating less catabolism by mammary tissue.

For IL, increased net uptake of $\operatorname{Arg}(P=0.02)$, His $(P=0.04)$, Ile $(P=0.04)$, Leu $(P<0.01)$, and Phe $(P<0.01)$ was observed (Table 6$)$. Net uptake of Ile and Leu increased by 19 and $27 \%$, respectively, for IL (Supplemental Table S6, https://doi.org/10.3168/jds .2019-17082), which compares closely to the $29.5 \%$ and $34.6 \%$ increases in venous concentrations of Ile and Leu (Supplemental Table S5, https://doi.org/10.3168/ jds.2019-17082). Greater capture of these EAA likely increased intracellular concentrations, which should facilitate greater activation of the mTORC1 pathway and substrate for NEAA synthesis, the latter negating the need for greater uptake of Asn, Gln, and Ser, as observed with MKH. Despite a 30- $\mu M$ drop in Val arterial concentration $(P=0.03)$, net uptake increased numerically $(P=0.54)$, driven by a higher Val clearance rate $(P=0.09)$ and greater MPF. The lack of response in Met and Tyr uptake is difficult to explain, as synthesis by the mammary gland is minimal to nonexistent for these AA, so how greater milk protein yield resulted without greater uptake is perplexing. In goats, as much as $18 \%$ of milk protein Met and $14 \%$ of milk protein Tyr may be derived from peptide uptake by the udder (Bequette et al., 1999). However, these values are overestimated, as pointed out by Hanigan et al. (1998b), due to very slow exchange with body protein pools, but one cannot rule out contributions from peptides containing Met and Tyr. Overall, the aggregate of total amino acids (TAA; $P=0.09)$, EAA $(P=0.01)$, and BCAA $(P=0.02)$ all increased or tended to increase in net uptake for IL. The net uptake AA responses in general match with expectations given changes in MPF that altogether would support greater protein yield and demonstrate the metabolic flexibility of the udder for securing AA.

\section{Mammary AA Clearance Rates}

Mammary AA clearance rates are listed in Table 7 . Clearance of TAA increased $(P=0.02)$ with MKH but did not change for IL (Table 7). Assuming mammary demand is a determinant of transport activity, there may not have been a need for additional transport activity given the increase in TAA supply driven by increased MPF with IL. Histidine and Met clearance rates dropped by $31 \%(P=0.01)$ and $64 \%(P<0.01)$, respectively, with $\mathrm{MKH}$. These EAA generally are not taken up in excess when supply increases above mammary demand for milk protein (Lapierre et al., 2012), so the dramatic decrease in clearance likely indicates that these EAA were oversupplied with MKH. Clearance rates of Phe $(P<0.01)$, Val $(P=0.02)$, Gly $(P$ $=0.01)$, and Ser $(P=0.07)$ all increased or tended to increase for $\mathrm{MKH}$, which reflects greater affinity for extracting these AA from extracellular space and should reduce their availability for splanchnic catabolism. Clearance of Lys (which was also infused) did not change despite greater supplies $(P=0.95)$. This lack of change in clearance of Lys reflects varying proportions of Lys destined for catabolism or other non-milk protein metabolic demand sinks in the udder. Clearance of BCAA $(P<0.01)$ and EAA other than Met, 
Table 7. Mammary clearance rates $(\mathrm{L} / \mathrm{h})$ of AA (least squares treatment means) ${ }^{1}$

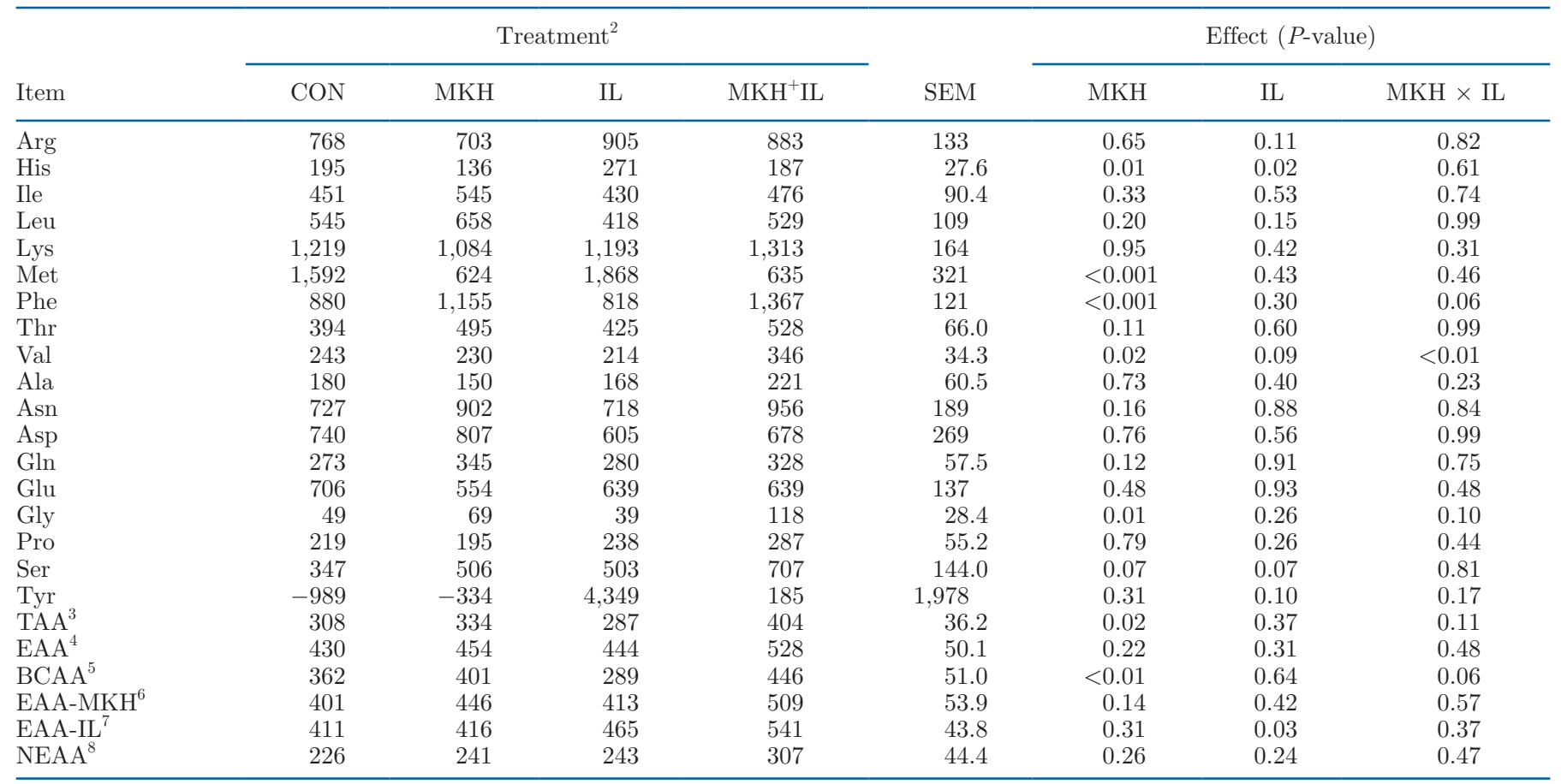

${ }^{1}$ Data represent arterial and venous measurements $(\mathrm{n}=6$ to 11 samples per cow) taken on $\mathrm{d} 16$.

${ }^{2} \mathrm{CON}=$ infused $3 \mathrm{~L}$ of $0.9 \%$ saline; $\mathrm{MKH}=$ infused $21 \mathrm{~g} / \mathrm{d}$ of Met, $20 \mathrm{~g} / \mathrm{d}$ of His, and $38 \mathrm{~g} / \mathrm{d}$ of Lys; IL = infused $22 \mathrm{~g} / \mathrm{d}$ of Ile and $50 \mathrm{~g} / \mathrm{d}$ of Leu; $\mathrm{MKH}^{+} \mathrm{IL}=$ infused $21 \mathrm{~g} / \mathrm{d}$ of Met, $20 \mathrm{~g} / \mathrm{d}$ of His, $38 \mathrm{~g} / \mathrm{d}$ of Lys, $22 \mathrm{~g} / \mathrm{d}$ of Ile, and $50 \mathrm{~g} / \mathrm{d}$ of Leu.

${ }^{3} \mathrm{TAA}=$ total AA $(\mathrm{EAA}+\mathrm{NEAA})$.

${ }^{4} \mathrm{EAA}=$ Arg, His, Ile, Leu, Lys, Met, Phe, Thr, and Val.

${ }^{5} \mathrm{BCAA}=$ branched-chain AA: Ile, Leu, and Val.

${ }^{6} \mathrm{EAA}-\mathrm{MKH}=\mathrm{Arg}$, Ile, Leu, Phe, Thr, and Val.

${ }^{7} \mathrm{EAA}-\mathrm{IL}=\mathrm{Arg}$, His, Lys, Met, Phe, Thr, and Val.

${ }^{8} \mathrm{NEAA}=$ Ala, Asn, Asp, Gln, Glu, Gly, Pro, Ser, and Tyr.

Lys, and His $(P=0.14)$ increased in response to $\mathrm{MKH}$, which again reflects greater pull from mammary tissue for these AA.

Similar increases in clearance rates of noninfused AA were also observed with $\operatorname{Arg}(P=0.11)$, His $(P$ $=0.02)$, Val $(P=0.09)$, Ser $(P=0.07)$, and the EAA other than Ile and Leu $(P=0.03)$ with IL treatment infusion, again to support the greater milk protein yield (Table 7). Clearance rates of Ile and Leu did not change despite increased concentrations associated with the treatment infusions. The latter likely reflects varying proportions of Ile and Leu being catabolized or utilized for non-milk protein functions in the udder.

\section{Ratio of Mammary AA Uptake to Milk AA Output}

The ratios of mammary AA uptake to milk protein output are provided in Table 8. The capture of extracted TAA into milk protein averaged $90 \%$ across treatments, which agrees precisely with previous findings of Cant et al. (1993; Table 8). The capture of extracted His,
Met, Phe, and Tyr averaged close to $100 \%$, whereas Arg, Ile, Leu, Lys, Thr, and Val were much lower. Of the infused EAA for MKH, only Lys increased in the uptake-to-output ratio, as is usually observed (Lapierre et al., 2009). The uptake-to-output ratio declined for BCAA $(P=0.07)$ and the sum of EAA minus Met, Lys, and His, which means less catabolism or transamination in the udder, which might explain the decline in lactose concentration because of a reduction in cellular energy status. The ratio for one NEAA, Glu $(P$ $<0.01$ ), declined, whereas the ratio for Ser increased $(P=0.02)$. Lysine is used to synthesize Glu (Lapierre et al., 2009), and the $31.7 \%$ increase in net Lys uptake likely reduced demand for extracellular Glu, given a much larger Lys precursor pool to synthesize Glu. In contrast, Ser intracellular synthesis may have decreased due to reduced intracellular BCAA with MKH (Roets et al., 1979; Roets et al., 1983), thereby necessitating greater uptake $(P<0.01)$ to support milk synthesis. These changes are reflected in a higher uptake-tooutput ratio for Ser $(P=0.07)$. The Ser ratio was not 
Table 8. Effect of AA infusions on ratio of mammary AA uptake to milk protein output (least squares treatment means) ${ }^{1}$

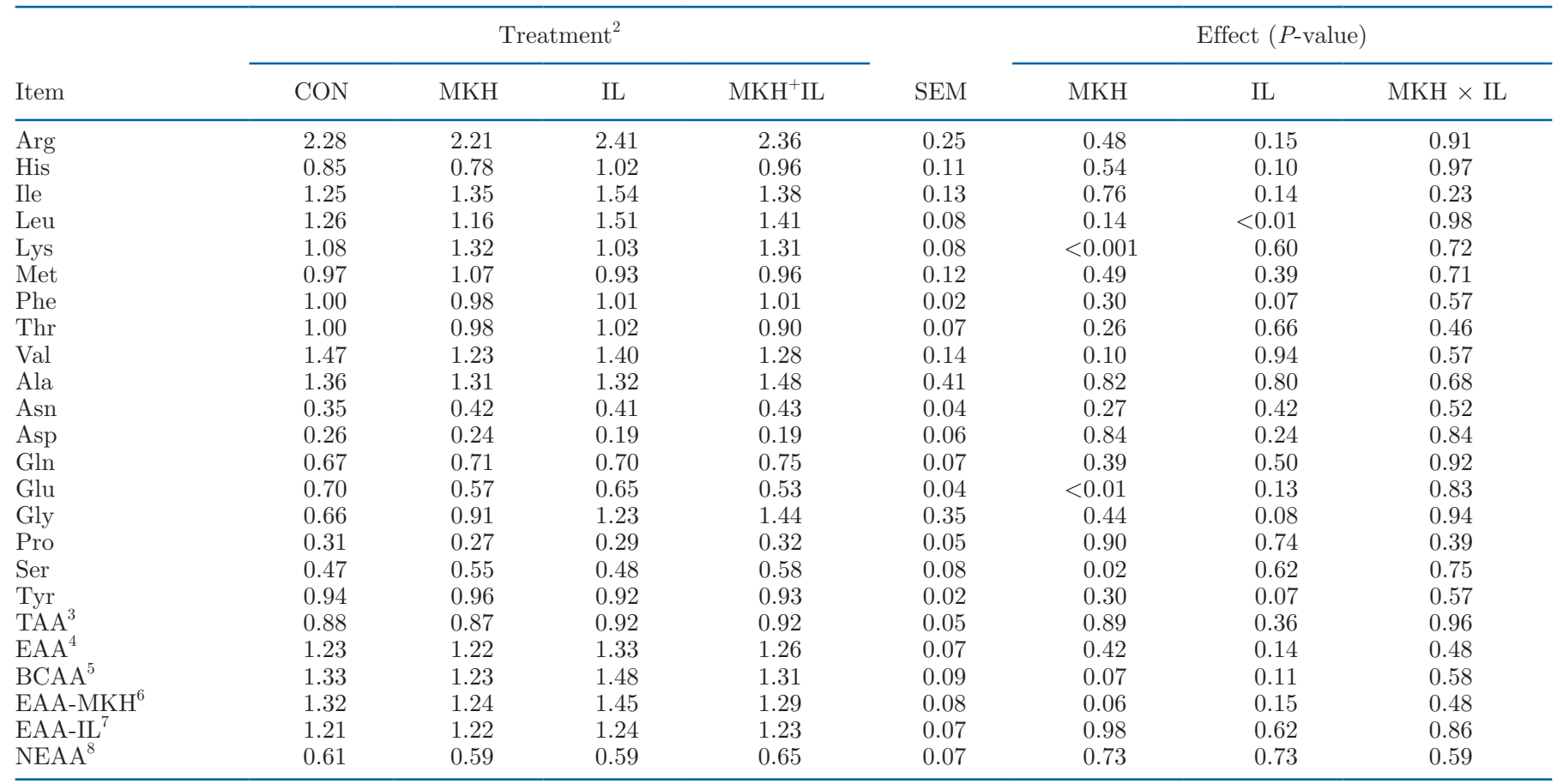

${ }^{1}$ Data represent arterial and venous measurements $(\mathrm{n}=6$ to 11 samples per cow) taken on d 16 and average milk AA yield from d 15 to 17 , between 1300 and $0100 \mathrm{~h}$.

${ }^{2} \mathrm{CON}=$ infused $3 \mathrm{~L}$ of $0.9 \%$ saline; MKH $=$ infused $21 \mathrm{~g} / \mathrm{d}$ of Met, $20 \mathrm{~g} / \mathrm{d}$ of His, and $38 \mathrm{~g} / \mathrm{d}$ of Lys; IL = infused $22 \mathrm{~g} / \mathrm{d}$ of Ile and $50 \mathrm{~g} / \mathrm{d}$ of Leu; $\mathrm{MKH}^{+} \mathrm{IL}=$ infused $21 \mathrm{~g} / \mathrm{d}$ of Met, $20 \mathrm{~g} / \mathrm{d}$ of His, $38 \mathrm{~g} / \mathrm{d}$ of Lys, $22 \mathrm{~g} / \mathrm{d}$ of Ile, and $50 \mathrm{~g} / \mathrm{d}$ of Leu.

${ }^{3} \mathrm{TAA}=$ total $\mathrm{AA}(\mathrm{EAA}+\mathrm{NEAA})$.

${ }^{4} \mathrm{EAA}=$ Arg, His, Ile, Leu, Lys, Met, Phe, Thr, and Val.

${ }^{5} \mathrm{BCAA}=$ branched-chain AA: Ile, Leu, and Val.

${ }^{6} \mathrm{EAA}-\mathrm{MKH}=\mathrm{Arg}$, Ile, Leu, Phe, Thr, and Val.

${ }^{7} \mathrm{EAA}-\mathrm{IL}=\mathrm{Arg}$, His, Lys, Met, Phe, Thr, and Val.

${ }^{8} \mathrm{NEAA}=$ Ala, Asn, Asp, Gln, Glu, Gly, Pro, Ser, and Tyr.

affected by IL $(P=0.62)$ despite a similar increase in milk protein yield; however, Leu and Ile net flux to the udder increased significantly, thereby providing substrate for Ser synthesis.

The ratio of Leu uptake to milk protein increased $21 \%(P<0.01)$ for IL (Table 8$)$. This change is usually observed when higher amounts of Leu are present in arterial blood (Bequette et al., 1996). However, increased Ile supply with IL did not change the uptake-to-output ratio, although it was numerically higher $(P=0.14)$. The ratio of Gly uptake to milk protein also tended to increase $(P=0.08)$ for IL, which likely reflects reduced Gly intracellular synthesis. This might have occurred because the substrates for Gly synthesis are primarily Thr (Verbeke et al., 1972) and Val (Roets et al., 1979), and both of these declined in arterial concentration $(P=0.10$ and $P=0.03)$ and were unchanged in net uptake, hence less availability for Gly synthesis. In general, changes in ratios of AA uptake to output were as expected, in that changes in arterial supply translated to changes in flux and proportion catabolized by the udder.

\section{Conversion Efficiency of AA to Milk Protein}

The efficiencies of converting metabolizable AA supplies into milk protein are listed in Table 9. The observed efficiency of conversion of predicted absorbed TAA to milk protein averaged $84.3 \%$ across treatments after accounting for maintenance requirements (Table 9). The underprediction of milk yield by 10 to $11 \mathrm{~kg} / \mathrm{d}$ by the NRC (2001) and CNCPS v. 6.55 models is likely caused by efficiency that is too low (unlikely) or maintenance costs that are too high. Efficiencies of AA greater than 100\% (i.e., His, Ile, Lys, Met, and Val) are not possible. This indicates either that the profile of absorbed AA utilized for maintenance is different from that utilized for milk protein production, or that AA were being mobilized from a source we had not considered (e.g., muscle tissue). From the perspective of 


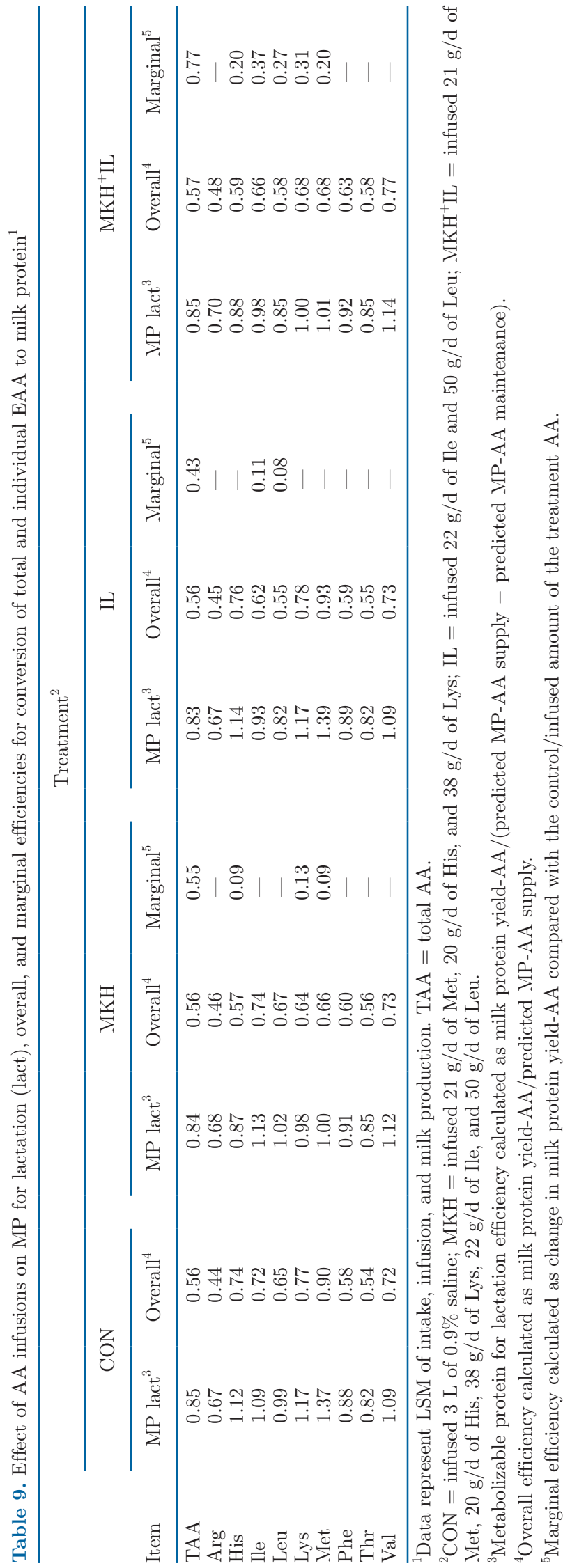

overall efficiency (milk protein yield to MP supply), the observed efficiencies for the aggregate and individual EAA seem more appropriate. Indeed, the overall individual EAA efficiencies for the 3 treatment means are similar to what has previously been derived from model development literature data sets (Van Amburgh et al., 2015; Martineau et al., 2016). The total AA marginal efficiency of the treatments was much higher than that commonly observed for infused EAA or casein (15 to 25\%; Hanigan et al., 1998a; Doelman et al., 2015a), ranging from 43 to $77 \%$. The marginal efficiencies of MKH and IL alone were less than overall efficiency, implying declining responses as supply increases, whereas the combination of MKH and IL increased marginal efficiency above the overall efficiency, implying that all AA as a sum were used more efficiently for milk protein. That the marginal efficiency did not improve for MKH, which involved commonly described limiting EAA, implies that one or more of those EAA were oversupplied or that other EAA were co-limiting. Our observations that infusion of other EAA (i.e., Ile and Leu) doubled the marginal efficiency of supplemental Met, Lys, and His implies that consideration for other EAA beyond the AA currently viewed as limiting may be necessary when formulating diets in lactating dairy cows.

\section{CONCLUSIONS}

Supplementing 2 groups of EAA, (1) Met, Lys, and His and (2) Ile and Leu, independently and additively increased milk protein yield in high-producing dairy cows. These outcomes suggest we may need to move beyond the single-limiting AA theory that is often encompassed in a barrel-stave visual for understanding regulation of milk protein yield. Increased supplies of Ile and Leu increased milk and ECM yields in dairy cows, which appeared to be facilitated by increased mammary plasma flow. Increased milk protein yield by these 2 groups of AA was assisted by changes in arterial AA concentrations, mammary plasma flow, and udder clearance rates of AA, which yielded altered net uptake. We also found changes in the proportion of AA catabolized and used for milk protein, which demonstrated plasticity in mammary protein metabolism. In summary, other EAA beyond Met, Lys, and His may be critical in optimizing dairy cattle performance when formulating lactating cow diets based on these results.

\section{ACKNOWLEDGMENTS}

The authors thank George Betton and Normand StPierre of Perdue AgriBusiness LLC (Salisbury, MD) for the generous financial support of P. S. Yoder and 
for the experimental work. The other authors have not stated any conflicts of interest. Additionally, the pharmaceutical-grade AA used in the trial were donated by Claudia Parys of Evonik Nutrition and Care GmbH (Hanau, Germany). The authors also appreciate the labor, expertise, and support of laboratory technician Tara Wiles, the undergraduate students, and the Dairy Science farm staff of Virginia Tech (Blacksburg, VA).

\section{REFERENCES}

Appuhamy, J. A., J. R. Knapp, O. Becvar, J. Escobar, and M. D. Hanigan. 2011. Effects of jugular-infused lysine, methionine, and branched-chain amino acids on milk protein synthesis in high-producing dairy cows. J. Dairy Sci. 94:1952-1960. https://doi.org/10 $.3168 /$ jds.2010-3442.

Appuhamy, J. A., N. A. Knoebel, W. A. Nayananjalie, J. Escobar, and M. D. Hanigan. 2012. Isoleucine and leucine independently regulate mTOR signaling and protein synthesis in MAC-T cells and bovine mammary tissue slices. J. Nutr. 142:484-491. https:// doi.org/10.3945/jn.111.152595.

Arriola Apelo, S. I., A. L. Bell, K. Estes, J. Ropelewski, M. J. de Veth, and M. D. Hanigan. 2014a. Effects of reduced dietary protein and supplemental rumen-protected essential amino acids on the nitrogen efficiency of dairy cows. J. Dairy Sci. 97:5688-5699. https:// doi.org/10.3168/jds.2013-7833.

Arriola Apelo, S. I., L. M. Singer, X. Y. Lin, M. L. McGilliard, N. R. St-Pierre, and M. D. Hanigan. 2014b. Isoleucine, leucine, methionine, and threonine effects on mammalian target of rapamycin signaling in mammary tissue. J. Dairy Sci. 97:1047-1056. https:// doi.org/10.3168/jds.2013-7348.

Arriola Apelo, S. I., L. M. Singer, W. K. Ray, R. F. Helm, X. Y. Lin, M. L. McGilliard, N. R. St-Pierre, and M. D. Hanigan. 2014c. Casein synthesis is independently and additively related to individual essential amino acid supply. J. Dairy Sci. 97:2998-3005. https:// doi.org/10.3168/jds.2013-7422.

Baird, T. D., and R. C. Wek. 2012. Eukaryotic initiation factor 2 phosphorylation and translational control in metabolism. Adv. Nutr. 3:307-321. https://doi.org/10.3945/an.112.002113.

Bauman, D. E., K. J. Harvatine, and A. L. Lock. 2011. Nutrigenomics, rumen-derived bioactive fatty acids, and the regulation of milk fat synthesis. Annu. Rev. Nutr. 31:299-319. https://doi.org/10.1146/ annurev.nutr.012809.104648.

Bequette, B. J., F. R. C. Backwell, C. E. Kyle, A. G. Calder, V. Buchan, L. A. Crompton, J. France, and J. C. Macrae. 1999. Vascular sources of phenylalanine, tyrosine, lysine, and methionine for casein synthesis in lactating goats. J. Dairy Sci. 82:362-377. https:/ /doi.org/10.3168/jds.S0022-0302(99)75243-4.

Bequette, B. J., F. R. Backwell, J. C. MacRae, G. E. Lobley, L. A. Crompton, J. A. Metcalf, and J. D. Sutton. 1996. Effect of intravenous amino acid infusion on leucine oxidation across the mammary gland of the lactating goat. J. Dairy Sci. 79:2217-2224. https://doi .org/10.3168/jds.S0022-0302(96)76598-0.

Bequette, B. J., M. D. Hanigan, A. G. Calder, C. K. Reynolds, G. E. Lobley, and J. C. MacRae. 2000. Amino acid exchange by the mammary gland of lactating goats when histidine limits milk production. J. Dairy Sci. 83:765-775. https://doi.org/10.3168/jds .S0022-0302(00)74939-3.

Calder, A. G., K. E. Garden, S. E. Anderson, and G. E. Lobley. 1999. Quantitation of blood and plasma amino acids using isotope dilution electron impact gas chromatography/mass spectrometry with U-(13)C amino acids as internal standards. Rapid Commun. Mass Spectrom. 13:2080-2083. https://doi.org/10.1002/(SICI)1097 -0231(19991115)13:21<2080::AID-RCM755>3.0.CO;2-O.

Cant, J. P., E. J. DePeters, and R. L. Baldwin. 1993. Mammary amino acid utilization in dairy cows fed fat and its relationship to milk protein depression. J. Dairy Sci. 76:762-774. https://doi.org/10 .3168/jds.S0022-0302(93)77400-7.
Cant, J. P., J. J. M. Kim, S. R. L. Cieslar, and J. Doelman. 2018. Symposium review: Amino acid uptake by the mammary glands: Where does the control lie? J. Dairy Sci. 101:5655-5666. https:// doi.org/10.3168/jds.2017-13844.

Cant, J. P., T. G. Madsen, and S. R. Cieslar. 2016. Predicting extraction and uptake of arterial energy metabolites by the mammary glands of lactating cows when blood flow is perturbed. J. Dairy Sci. 99:718-732. https://doi.org/10.3168/jds.2015-9366.

Cieslar, S. R., T. G. Madsen, N. G. Purdie, D. R. Trout, V. R. Osborne, and J. P. Cant. 2014. Mammary blood flow and metabolic activity are linked by a feedback mechanism involving nitric oxide synthesis. J. Dairy Sci. 97:2090-2100. https://doi.org/10.3168/jds .2013-6961.

Curtis, R. V., J. J. M. Kim, J. Doelman, and J. P. Cant. 2018. Maintenance of plasma branched-chain amino acid concentrations during glucose infusion directs essential amino acids to extra-mammary tissues in lactating dairy cows. J. Dairy Sci. 101:4542-4553. https: //doi.org/10.3168/jds.2017-13236.

Daley, V. L., C. Dye, C. Bogers, R. M. Akers, F. C. Rodriguez, J. P. Cant, J. Doelman, P. S. Yoder, K. Kumar, D. Webster, and M. D. Hanigan. 2018. Bovine mammary gland biopsy techniques. J. Vis. Exp. 142:e58602.

Doelman, J., R. V. Curtis, M. Carson, J. J. Kim, J. A. Metcalf, and J. P. Cant. 2015a. Essential amino acid infusions stimulate mammary expression of eukaryotic initiation factor $2 \mathrm{~B} \varepsilon$ but milk protein yield is not increased during an imbalance. J. Dairy Sci. 98:44994508. https://doi.org/10.3168/jds.2014-9051.

Doelman, J., J. J. Kim, M. Carson, J. A. Metcalf, and J. P. Cant. 2015b. Branched-chain amino acid and lysine deficiencies exert different effects on mammary translational regulation. J. Dairy Sci. 98:7846-7855. https://doi.org/10.3168/jds.2015-9819.

Doepel, L., I. I. Hewage, and H. Lapierre. 2016. Milk protein yield and mammary metabolism are affected by phenylalanine deficiency but not by threonine or tryptophan deficiency. J. Dairy Sci. 99:31443156. https://doi.org/10.3168/jds.2015-10320.

Emery, R. S., L. D. Brown, and J. W. Bell. 1965. Correlation of milk fat with dietary and metabolic factors in cows fed restrictedroughage rations supplemented with magnesium oxide or sodium bicarbonate. J. Dairy Sci. 48:1647-1651. https://doi.org/10.3168/ jds.S0022-0302(65)88543-5.

Estes, K. A., R. R. White, P. S. Yoder, T. Pilonero, H. Schramm, H. Lapierre, and M. D. Hanigan. 2018. An in vivo stable isotopebased approach for assessment of absorbed amino acids from individual feed ingredients within complete diets. J. Dairy Sci. 101:7040-7060. https://doi.org/10.3168/jds.2017-13447.

Giallongo, F., M. T. Harper, J. Oh, J. C. Lopes, H. Lapierre, R. A. Patton, C. Parys, I. Shinzato, and A. N. Hristov. 2016. Effects of rumen-protected methionine, lysine, and histidine on lactation performance of dairy cows. J. Dairy Sci. 99:4437-4452. https://doi .org/10.3168/jds.2015-10822.

Giallongo, F., M. T. Harper, J. Oh, C. Parys, I. Shinzato, and A. N. Hristov. 2017. Histidine deficiency has a negative effect on lactational performance of dairy cows. J. Dairy Sci. 100:2784-2800. https://doi.org/10.3168/jds.2016-11992.

Gu, X., J. M. Orozco, R. A. Saxton, K. J. Condon, G. Y. Liu, P. A. Krawczyk, S. M. Scaria, J. W. Harper, S. P. Gygi, and D. M. Sabatini. 2017. SAMTOR is an S-adenosylmethionine sensor for the mTORC1 pathway. Science 358:813-818. https://doi.org/10.1126/ science.aao3265.

Guo, C. L., Y. T. Li, X. Y. Lin, M. D. Hanigan, Z. G. Yan, Z. Y. Hu, Q. L. Hou, F. G. Jiang, and Z. H. Wang. 2017. Effects of graded removal of lysine from an intravenously infused amino acid mixture on lactation performance and mammary amino acid metabolism in lactating goats. J. Dairy Sci. 100:4552-4564. https://doi.org/10 $.3168 /$ jds.2016-11921.

Hanigan, M. D., C. C. Calvert, E. J. DePeters, B. L. Reis, and R. L. Baldwin. 1991. Whole blood and plasma amino acid uptakes by lactating bovine mammary glands. J. Dairy Sci. 74:2484-2490. https://doi.org/10.3168/jds.S0022-0302(91)78425-7.

Hanigan, M. D., J. P. Cant, D. C. Weakley, and J. L. Beckett. 1998a. An evaluation of postabsorptive protein and amino acid metabo- 
lism in the lactating dairy cow. J. Dairy Sci. 81:3385-3401. https: //doi.org/10.3168/jds.S0022-0302(98)75903-X.

Hanigan, M. D., J. France, L. A. Crompton, and B. J. Bequette. 2000. Evaluation of a representation of the limiting amino acid theory for milk protein synthesis. Pages 127-144 in Modelling Nutrient Utilization in Farm Animals. J. P. McNamara, J. France, D. Beever, ed. CABI, Oxford, UK.

Hanigan, M. D., J. France, D. Wray-Cahen, D. E. Beever, G. E. Lobley, L. Reutzel, and N. E. Smith. 1998b. Alternative models for analyses of liver and mammary transorgan metabolite extraction data. Br. J. Nutr. 79:63-78. https://doi.org/10.1079/BJN19980010.

Hanigan, M. D., H. Lapierre, R. Martineau, and A. M. Myers. 2018. Predicting milk protein production from amino acid supply. J. Dairy Sci. 101(E-Suppl. 2):410. (Abstr.)

Hanigan, M. D., C. K. Reynolds, D. J. Humphries, B. Lupoli, and J. D. Sutton. 2004. A model of net amino acid absorption and utilization by the portal-drained viscera of the lactating dairy cow. J. Dairy Sci. 87:4247-4268. https://doi.org/10.3168/jds.S0022 $-0302(04) 73570-5$.

Hristov, A. N., W. J. Price, and B. Shafii. 2004. A meta-analysis examining the relationship among dietary factors, dry matter intake, and milk and milk protein yield in dairy cows. J. Dairy Sci. 87:2184-2196. https://doi.org/10.3168/jds.S0022-0302(04)70039 $-9$.

Huhtanen, P., A. Vanhatalo, and T. Varvikko. 2002. Effects of abomasal infusions of histidine, glucose, and leucine on milk production and plasma metabolites of dairy cows fed grass silage diets. J. Dairy Sci. 85:204-216. https://doi.org/10.3168/jds.S0022 $-0302(02) 74069-1$.

Kassube, K. R., J. D. Kaufman, K. G. Pohler, J. W. McFadden, and A. G. Rius. 2017. Jugular-infused methionine, lysine and branchedchain amino acids does not improve milk production in Holstein cows experiencing heat stress. Animal 11:2220-2228. https://doi .org/10.1017/S1751731117001057.

Korhonen, M., A. Vanhatalo, and P. Huhtanen. 2002. Evaluation of isoleucine, leucine, and valine as a second-limiting amino acid for milk production in dairy cows fed grass silage diet. J. Dairy Sci. 85:1533-1545. https://doi.org/10.3168/jds.S0022-0302(02)74223 $-9$.

Lapierre, H., L. Doepel, E. Milne, and G. E. Lobley. 2009. Responses in mammary and splanchnic metabolism to altered lysine supply in dairy cows. Animal 3:360-371. https://doi.org/10.1017/ S1751731108003571.

Lapierre, H., G. E. Lobley, L. Doepel, G. Raggio, H. Rulquin, and S. Lemosquet. 2012. Triennial lactation symposium: Mammary metabolism of amino acids in dairy cows. J. Anim. Sci. 90:1708-1721. https://doi.org/10.2527/jas.2011-4645.

Lapierre, H., D. R. Ouellet, L. Doepel, G. Holtrop, and G. E. Lobley. 2008. Histidine, lysine, and methionine: From metabolism to balanced dairy rations. Pages 19-36 in Proc. 44th Eastern Nutrition Conference of Canada (ANAC). University of Guelph, Guelph, ON, Canada.

LaRosa, P. C., J. J. Riethoven, H. Chen, Y. Xia, Y. Zhou, M. Chen, J. Miner, and M. E. Fromm. 2007. Trans-10, cis-12 conjugated linoleic acid activates the integrated stress response pathway in adipocytes. Physiol. Genomics 31:544-553. https://doi.org/10.1152/ physiolgenomics.00156.2007.

Lean, I. J., M. B. de Ondarza, C. J. Sniffen, J. E. P. Santos, and K. E. Griswold. 2018. Meta-analysis to predict the effects of metabolizable amino acids on dairy cattle performance. J. Dairy Sci. 101:340-364. https://doi.org/10.3168/jds.2016-12493.

Lee, C., A. N. Hristov, T. W. Cassidy, K. S. Heyler, H. Lapierre, G. A. Varga, M. J. de Veth, R. A. Patton, and C. Parys. 2012. Rumenprotected lysine, methionine, and histidine increase milk protein yield in dairy cows fed a metabolizable protein-deficient diet. J. Dairy Sci. 95:6042-6056. https://doi.org/10.3168/jds.2012-5581.

Liu, G. M., M. D. Hanigan, X. Y. Lin, K. Zhao, F. G. Jiang, R. R. White, Y. Wang, Z. Y. Hu, and Z. H. Wang. 2017. Methionine, leucine, isoleucine, or threonine effects on mammary cell signaling and pup growth in lactating mice. J. Dairy Sci. 100:4038-4050. https://doi.org/10.3168/jds.2016-11973.
Martineau, R., D. R. Ouellet, E. Kebreab, and H. Lapierre. 2016. Casein infusion rate influences feed intake differently depending on metabolizable protein balance in dairy cows: A multilevel metaanalysis. J. Dairy Sci. 99:2748-2761. https://doi.org/10.3168/jds .2015-10427.

McBeth, L. R., N. R. St-Pierre, D. E. Shoemaker, and W. P. Weiss. 2013. Effects of transient changes in silage dry matter concentration on lactating dairy cows. J. Dairy Sci. 96:3924-3935. https:// doi.org/10.3168/jds.2012-6330.

Mitchell, H. H., and R. J. Block. 1946. Some relationships between the amino acid contents of proteins and their nutritive values for the rat. J. Biol. Chem. 163:599-620.

Myers, A. J., H. Lapierre, R. R. White, H. Tran, P. J. Kononoff, R. Martineau, W. P. Weiss, and M. D. Hanigan. 2018. Predictions of rumen outflow of amino acids in dairy cattle. J. Dairy Sci. 101(ESuppl. 2):410. (Abstr.)

Nichols, K., J. Doelman, J. J. M. Kim, M. Carson, J. A. Metcalf, and J. P. Cant. 2017. Exogenous essential amino acids stimulate an adaptive unfolded protein response in the mammary glands of lactating cows. J. Dairy Sci. 100:5909-5921. https://doi.org/10 .3168/jds.2016-12387.

Noftsger, S., and N. R. St-Pierre. 2003. Supplementation of methionine and selection of highly digestible rumen undegradable protein to improve nitrogen efficiency for milk production. J. Dairy Sci. 86:958-969. https://doi.org/10.3168/jds.S0022-0302(03)73679-0.

NRC (National Research Council). 2001. Nutrient Requirements of Dairy Cattle. 7th rev. ed. National Academies Press, Washington, DC.

Prosser, C. G., S. R. Davis, V. C. Farr, and P. Lacasse. 1996. Regulation of blood flow in the mammary microvasculature. J. Dairy Sci. 79:1184-1197. https://doi.org/10.3168/jds.S0022-0302(96)76472 $-\mathrm{X}$.

Purdie, N. G., D. R. Trout, S. R. Cieslar, T. G. Madsen, D. P. Poppi, and J. P. Cant. 2009. The effect of short-term hyperammonaemia on milk synthesis in dairy cows. J. Dairy Res. 76:49-58. https:// doi.org/10.1017/S0022029908003634.

R Core Team. 2017. A Language and Environment for Statistical Computing. R Foundation for Statistical Computing, Vienna, Austria.

Rius, A. G., J. A. Appuhamy, J. Cyriac, D. Kirovski, O. Becvar, J. Escobar, M. L. McGilliard, B. J. Bequette, R. M. Akers, and M. D. Hanigan. 2010. Regulation of protein synthesis in mammary glands of lactating dairy cows by starch and amino acids. J. Dairy Sci. 93:3114-3127. https://doi.org/10.3168/jds.2009-2743.

Robinson, P. H., W. Chalupa, C. J. Sniffen, W. E. Julien, H. Sato, T. Fujieda, T. Ueda, and H. Suzuki. 2000. Influence of abomasal infusion of high levels of lysine or methionine, or both, on ruminal fermentation, eating behavior, and performance of lactating dairy cows. J. Anim. Sci. 78:1067-1077. https://doi.org/10.2527/2000 $.7841067 x$.

Roets, E., A. M. Massart-Leen, G. Peeters, and R. Verbeke. 1983. Metabolism of leucine by the isolated perfused goat udder. J. Dairy Res. 50:413-424. https://doi.org/10.1017/S0022029900032647.

Roets, E., A. M. Massart-Leen, R. Verbeke, and G. Peeters. 1979. Metabolism of [U-14C; 2,3-3H]-L-valine by the isolated perfused goat udder. J. Dairy Res. 46:47-57. https://doi.org/10.1017/ S0022029900016848.

Rubert-Alemán, J., G. Rychen, F. Casseron, F. Laurent, and G. J. Martin. 1999. $15 \mathrm{~N}$ enrichment of casein amino acids in the milk from goats given a single intravenous dose of L-[15N]leucine. J. Dairy Res. 66:283-288. https://doi.org/10.1017/S0022029999003404.

Rulquin, H., and P. M. Pisulewski. 2006. Effects of graded levels of duodenal infusions of leucine on mammary uptake and output in lactating dairy cows. J. Dairy Res. 73:328-339. https://doi.org/10 $.1017 /$ S0022029906001841.

Sabatini, D. M. 2017. Twenty-five years of mTOR: Uncovering the link from nutrients to growth. Proc. Natl. Acad. Sci. USA 114:1181811825. https://doi.org/10.1073/pnas.1716173114.

Satter, L. D., R. L. Lang, J. W. Van Loo, M. E. Carlson, and R. W. Kepler. 1975. Adverse effect of excess methionine or methionine hydroxy analog on feed consumption in cattle. J. Dairy Sci 58:521-525. https://doi.org/10.3168/jds.S0022-0302(75)84601-7. 
Saxton, R. A., K. E. Knockenhauer, R. L. Wolfson, L. Chantranupong, M. E. Pacold, T. Wang, T. U. Schwartz, and D. M. Sabatini. 2016. Structural basis for leucine sensing by the Sestrin2-mTORC1 pathway. Science 351:53-58. https://doi.org/10.1126/science.aad2087.

Schwab, C. G., L. D. Satter, and B. Clay. 1976. Response to lactating dairy cows to abomasal infusion of amino acids. J. Dairy Sci. 59:1254-1270. https://doi.org/10.3168/jds.S0022-0302(76)84354 $-8$.

Shennan, D. B., and C. A. Boyd. 2014. The functional and molecular entities underlying amino acid and peptide transport by the mammary gland under different physiological and pathological conditions. J. Mammary Gland Biol. Neoplasia 19:19-33. https://doi .org/10.1007/s10911-013-9305-5.

Sinclair, K. D., P. C. Garnsworthy, G. E. Mann, and L. A. Sinclair. 2014. Reducing dietary protein in dairy cow diets: Implications for nitrogen utilization, milk production, welfare and fertility. Animal 8:262-274. https://doi.org/10.1017/S1751731113002139.

St-Pierre, N. R., and J. T. Sylvester. 2005. Effects of 2-hydroxy4-(methylthio) butanoic acid (HMB) and its isopropyl ester on milk production and composition by Holstein cows. J. Dairy Sci. 88:2487-2497. https://doi.org/10.3168/jds.S0022-0302(05)72926 $-\mathrm{X}$.

Tian, W., T. Wu, R. Zhao, J. Xu, Y. He, and H. Wang. 2017. Responses of milk production of dairy cows to jugular infusions of a mixture of essential amino acids with or without exclusion leucine or arginine. Anim. Nutr. 3:271-275. https://doi.org/10.1016/ j.aninu.2017.05.003.

Toerien, C. A., D. R. Trout, and J. P. Cant. 2010. Nutritional stimulation of milk protein yield of cows is associated with changes in phosphorylation of mammary eukaryotic initiation factor 2 and ribosomal s6 kinase 1. J. Nutr. 140:285-292. https://doi.org/10 $.3945 /$ jn.109.114033.

Van Amburgh, M. E., E. A. Collao-Saenz, R. J. Higgs, D. A. Ross, E. B. Recktenwald, E. Raffrenato, L. E. Chase, T. R. Overton, J. K. Mills, and A. Foskolos. 2015. The Cornell Net Carbohydrate and Protein System: Updates to the model and evaluation of version 6.5. J. Dairy Sci. 98:6361-6380. https://doi.org/10.3168/jds.2015 $-9378$.
Verbeke, R., E. Roets, A. M. Massart-Leen, and G. Peeters. 1972. Metabolism of (U-14 C)-L-threonine and (U-14 C)-L-phenylalanine by the isolated perfused udder. J. Dairy Res. 39:239-250. https:// doi.org/10.1017/S0022029900014072.

Vyas, D., and R. A. Erdman. 2009. Meta-analysis of milk protein yield responses to lysine and methionine supplementation. J. Dairy Sci 92:5011-5018. https://doi.org/10.3168/jds.2008-1769.

Weekes, T. L., P. H. Luimes, and J. P. Cant. 2006. Responses to amino acid imbalances and deficiencies in lactating dairy cows. J. Dairy Sci. 89:2177-2187. https://doi.org/10.3168/jds.S0022 -0302(06)72288-3.

Wolfson, R. L., L. Chantranupong, R. A. Saxton, K. Shen, S. M. Scaria, J. R. Cantor, and D. M. Sabatini. 2016. Sestrin2 is a leucine sensor for the mTORC1 pathway. Science 351:43-48. https:// doi.org/10.1126/science.aab2674.

Wolfson, R. L., and D. M. Sabatini. 2017. The dawn of the age of amino acid sensors for the mTORC1 pathway. Cell Metab. 26:301309. https://doi.org/10.1016/j.cmet.2017.07.001.

Yoder, P. S., N. R. St-Pierre, K. M. Daniels, K. M. O'Diam, and W. P. Weiss. 2013. Effects of short-term variation in forage quality and forage to concentrate ratio on lactating dairy cows. J. Dairy Sci. 96:6596-6609. https://doi.org/10.3168/jds.2013-6724.

Zanton, G. I., G. R. Bowman, M. Vazquez-Anon, and L. M. Rode. 2014. Meta-analysis of lactation performance in dairy cows receiving supplemental dietary methionine sources or postruminal infusion of methionine. J. Dairy Sci. 97:7085-7101. https://doi.org/10 $.3168 /$ jds.2014-8220.

\section{ORCIDS}

P. S. Yoder ๑ https://orcid.org/0000-0001-6646-1991

X. Huang (®) https://orcid.org/0000-0003-3890-039X

I. A. Teixeira ๑ https://orcid.org/0000-0002-7432-867X

J. P. Cant ๑ https://orcid.org/0000-0003-2021-1764

M. D. Hanigan (ํ) https://orcid.org/0000-0002-5639-9677 